\title{
6 La tercera generación de LTG: “los libros integrados"
}

La tercera generación de los libros de primer año fue utilizada por los niños mexicanos desde el curso escolar 1980-1981 y hasta 1993 (cuando se proclama una nueva reforma). A continuación, hablaremos del contexto sociopolítico en el que se gestaron y repartieron estos manuales. Expondremos las razones por las que estos libros volvieron a integrar todas las materias y sustituyeron a los anteriores a pesar de que no se presentó una nueva reforma educativa. Asimismo, expondremos el análisis que nos permitió dilucidar cómo se conformó el MCI de IDENTIDAD MEXICANA en los libros de los años ochenta.

\subsection{Contexto sociopolítico en que se crearon los LTG de primero de tercera generación}

El contexto en el que se utilizaron los libros de la tercera generación fue de mucha inestabilidad económica, ya que se registraron varias crisis financiarias (Aboites Aguilar 1998, p. 48). De 1979 a 1981 hubo un auge petrolero que significó una moderada elevación del nivel de vida, el fortalecimiento de la clase media, excesivas ganancias y derroches de grupos privilegiados (Torres Barreto 2007, p. 94), la inversión del gobierno en obras públicas y el endeudamiento con mercados internacionales. Sin embargo, en 1981 sobrevino una crisis debido a la reducción drástica del precio del petróleo y a la elevación de las tasas de interés de la deuda externa. En 1982, ante la gran crisis económica internacional, la fuga de capitales de inversión de México y el déficit en los ingresos, el gobierno mexicano decidió reducir el gasto público y devaluar la moneda. Para ese entonces, los bancos privados monopolizaban los créditos de la población a favor de las empresas, por lo que representaban el mayor obstáculo para la estabilización. Así, el 1o de septiembre el presidente José López Portillo (1976-1982), sucesor de Echeverría y último representante del nacionalismo político, declaró la expropiación bancaria. Esta acción, duramente criticada por los capitalistas mexicanos por afectar sus intereses, no tuvo el resultado esperado y la crisis empeoró.

Miguel de la Madrid Hurtado recibió el poder presidencial (1982-1988) dos meses después de la nacionalización de la banca, en condiciones de severa crisis económica. México en ese entonces sufría un colapso financiero, una inflación del 100\%, y había perdido el crédito externo y la confianza de los inversionistas. 
Los objetivos y medidas de la política económica del sexenio de De la Madrid giraron alrededor de los acuerdos con el Fondo Monetario Internacional y con los acreedores internacionales. Las estrategias de corte liberal que diseñó el gobierno fueron la adecuación de la economía al ejercicio pleno del capitalismo competitivo, el estímulo a la iniciativa privada, la atenuación de restricciones a las inversiones extranjeras y el empeño por pagar como fuera los intereses y amortizaciones de la deuda externa (Torres Barreto 2007, p. 106). Asimismo, para combatir la inflación que entre 1983 y 1984 llegó a más de 140\%, De la Madrid impuso una política de austeridad que consistió en la reducción de salarios. Esta estrategia conllevó, naturalmente, el deterioro de las condiciones de salud, educación y vivienda de la mayor parte de la población. A estas crisis se sumó el catastrófico terremoto de 1985 que destruyó la parte central de la Ciudad de México y al cual el gobierno respondió ineficazmente.

Ante su incapacidad para erradicar las crisis, el grupo en el poder difundió un discurso en el que atribuía al populismo de los gobiernos precedentes la deficiencia principal de la política mexicana. Así, De la Madrid inició la transformación del modelo nacional de populista-nacionalista a neoliberal.

La crisis de los ochenta repercutió en la educación: en esa década solo la mitad de los escolares terminaba la educación primaria; el PIB destinado a la educación disminuyó de 5.3\% en 1981 a 3.3\% en 1988; se cancelaron programas para combatir el rezago y dar mantenimiento a las escuelas; se estancó el número de matriculados en las escuelas normales; y muchos maestros se vieron en la necesidad de renunciar y buscar otros trabajos debido a la reducción de salarios de hasta el 45\% (Torres Barreto 2007, p. 109). En contraste, la inversión del sector educativo privado se incrementó en un 10\%. Las bajas percepciones salariales que tenían los maestros y las decisiones del gobierno dieron como resultado frecuentes conflictos políticos y sindicales, paros y marchas entre 1981 y 1989.

\subsubsection{La tercera generación de libros de primer año: “los libros integrados”}

La tercera generación de LTG de primero de primaria (1980-1993) no surge de una reforma educativa sino de una evaluación de los materiales a finales de 1978. En este año fue creado el Consejo de Contenidos y Métodos Educativos (a partir de aquí CCyME) que tuvo la tarea de proponer lineamientos para la revisión de contenidos, planes y programas de estudio, métodos educativos, así como de la concepción del diseño de los nuevos LTG. Después de la revisión, en 1978, de planes y libros vigentes, así como de una serie de consultas al magisterio nacional, se llegó al acuerdo de crear programas y LTG integrados para el primero y segundo grados y de mantener los mismos libros, organizados por 
áreas, para los grados del tercero al sexto. Además, la CCyME estipuló un programa de elaboración de monografías para cada uno de los Estados de la República que debían distribuirse antes de que terminara el sexenio presidencial.

El propósito de integrar los libros era el de ajustarlos a la teoría de la globalización de la enseñanza, la cual está fundamentada en las características psicológicas del niño, que hasta los ocho años tiene un pensamiento sincrético (Merino Huerta 1982, p. 318). Es decir, que hasta esa edad el niño percibe la realidad en conjuntos; por esta razón, la integración de los materiales tuvo como finalidad "presentar al alumno las cosas, los hechos, la realidad, tal como aparecen en su medio: como un todo unificado, superando así la perspectiva que ofrece cada una de las áreas, en que la realidad solo puede conocerse parcialmente" (Jaso García 1982, p. 262). Así, de acuerdo con Salcedo Aquino (1982, p. 45), los cambios que sufrieron los libros de esta generación fueron de forma y no de contenido. Los objetivos del proyecto de 1972 continuaron vigentes, la diferencia fue que en lugar de siete áreas programáticas se establecieron ocho, las cuales quedaron integradas solo en el caso del primer y segundo grados: Español, Matemáticas, Ciencias Naturales, Ciencias Sociales, Educación Tecnológica, Educación Artística, Educación Física y Educación para la Salud, siendo esta última la que se incluyó en el nuevo plan.

Después de dos ediciones experimentales de los nuevos materiales, en 1980 los niños de primer año recibieron los materiales, que continuaron vigentes hasta 1993. El paquete de libros de primero constaba de cuatro volúmenes notablemente más grandes que los de la generación anterior: Mi libro de primero. Parte I (239 páginas); Mi libro de primero. Parte II (230 páginas); Mi libro de primero recortable. Parte I (127 páginas), y Mi libro de primero recortable. Parte II (104 páginas). Las portadas de estos libros aludian nuevamente al marco cognitivo infantil: soles, arcoíris, mariposas, niños y niñas jugando con cometas fueron las imágenes que Carlos Pelleiro y Felipe Dávalos crearon para ilustrar los volúmenes de primero y segundo grado (Fig. 1).

Estos libros, sin embargo, cambiaron sus portadas en 1989 con la llegada como director de la CONALITEG (1984-1993) del abogado y diplomático Javier Wimer Zambrano. Wimer, amante del arte, mantenía amistad con numerosos artistas plásticos mexicanos pertenecientes a la llamada Generación de la Ruptura, la cual se posicionaba distante de la tradición muralística mexicana y las temáticas nacionalistas (Hernández 2011, p. 152). El director de la CONALITEG, pues, decidió continuar con la propuesta del primer director de esta institución, Martín Luis Guzmán, y junto con el equipo de diseño editorial, encabezado por Lenin Molina, convocó a 32 artistas mexicanos para el diseño de las nuevas portadas. Fernando Zertuche Muñoz, en ese entonces director general del Instituto Nacional de Educación para Adultos (INEA), habla en entrevista con Hernández 

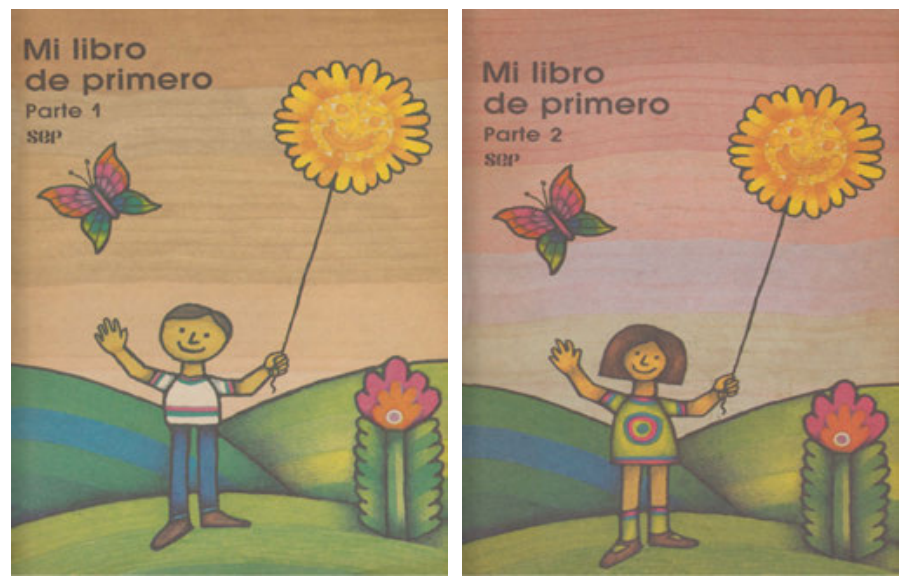

Fig. 1: Portadas de la tercera generación de LTG, edición 1980.

(2011, pp. 157-158) sobre los lineamientos ideológicos que guiaron el proyecto de renovación de las portadas:

De pronto me dice Lenin que se ha tomado una decisión: desde la portada, los libros deben llevar el mensaje de la cultura mexicana. Promover que los niños, así fueran muy pequeños, conocieran a los artistas plásticos más relevantes del país [. . .] El proyecto daba continuidad a los propósitos de Martín Luis Guzmán, en el sentido de que, de entrada, el libro de texto gratuito, desde la portada, tiene que darle algo al niño. . . eso lo expresaban tanto Javier como Lenin constantemente. $\mathrm{Y}$ jamás se permitieron hacer una crítica de las experiencias previas; eso sí, existía el ánimo de marcar su paso por la Comisión con algo diferente, con algo que fuera bueno y positivo. Y hay que decir, finalmente, que para un funcionario público como Wimer, también era importante demostrar su eficacia ante el secretario de Educación Pública y ante el presidente de la República.

Así, se logró reunir entre 1988 y 1990, 34 obras pictóricas de técnicas y estilos diferentes que fueron requeridas en calidad de donación. Sus creadores gozaron de total libertad creativa con la sola consigna de que su obra aludiera a los contenidos del libro que se les asignó. Las portadas para cada libro de primer año fueron realizadas por un pintor distinto (Xavier Esqueda, Joy Laville, Elvira Gascón, Guillermo Meza) y llegaron a manos de los niños a partir del ciclo escolar 1988-1989 (Fig. 2).

Como ya se mencionó, en esta generación se integran todas las áreas del conocimiento y se reparten en dos volúmenes con cuatro unidades cada uno. Las unidades no tienen título pero cada una incluye cuatro módulos titulados. Como en la generación precedente, se mantiene el libro recortable que también 

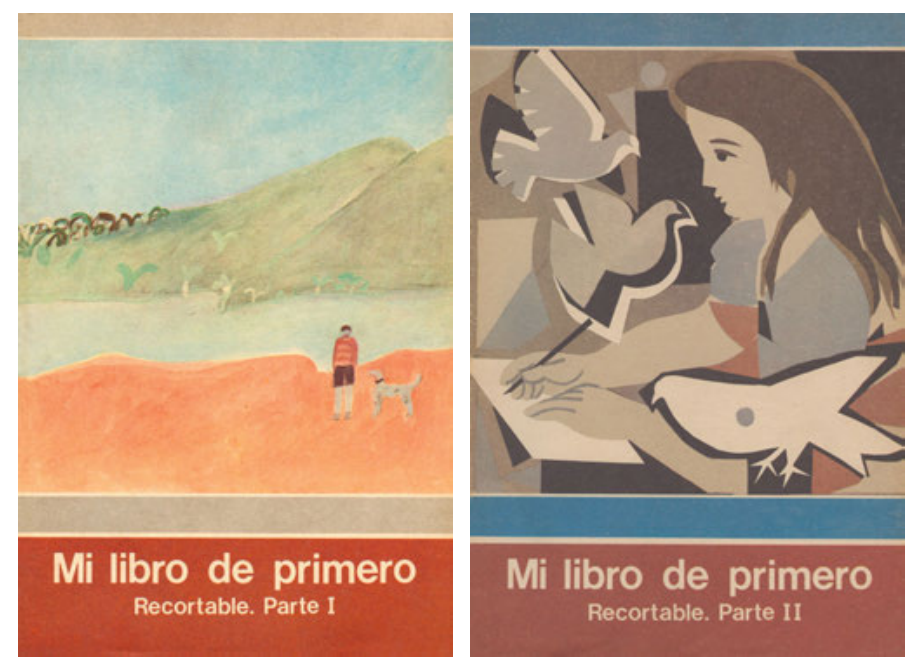

Fig. 2: Portadas de la tercera generación de LTG, edición 1987.

se divide en dos libros. Mi libro de primero. Parte I consta de 239 páginas y contiene las primeras cuatro unidades. La primera unidad tiene que ver con el reconocimiento del yo-niño. La segunda con el ambiente infantil inmediato (la familia, la casa, el juego). La tercera unidad trata temas de ciencias naturales (el nacimiento de las plantas y los animales) y un tema correspondiente al civismo (la colaboración). La cuarta unidad hace referencia al ambiente físico inmediato (la casa, el lugar en que vive, algunos recursos naturales). El volumen I termina con 52 páginas de lecturas. Este libro cuenta con su correspondiente libro recortable, Mi libro de primero recortable. Parte I, que consta de 127 páginas. Este comienza con 12 páginas con ejercicios en los que se le pide al niño el reconocimiento y clasificación de categorías (animales, sentimientos, muebles, etc.). Posteriormente se proponen actividades similares a las de la generación anterior que implican recortar y pegar. Mi libro de primero. Parte II contiene 230 páginas y cuatro unidades. La primera unidad de este volumen se asigna como unidad 5 por continuidad (por lo que comienza en la página 249) y trata la vida en el campo en contraste con la vida en la ciudad. La unidad 6 toca los temas de la casa, los vecinos y los animales. La séptima está dedicada a los lugares de México, los medios de comunicación y de transporte y la identidad mexicana. La última unidad trata el tiempo: el pasado, presente y futuro del niño, así como el pasado de México. 


\subsubsection{Controversias suscitadas por los libros integrados}

Esta década no se libró de las inconformidades y ataques contra el sistema educativo y los libros de texto. Los miembros de la derecha tradicional, incluidos empresarios y clero, así como la UNPF, seguían denunciando la orientación socialista del sistema educativo, que, afirmaban, generaba odio en los niños mexicanos. Asimismo, se quejaban de que los LTG coartaban la libertad del derecho que tenían los padres de educar a sus hijos. Así lo expresó José Ruiz Chávez, vocero de la UNPF, cuyas palabras aparecen el 23 de abril de 1984 en el semanario de opinión y análisis político Proceso:

[. . .] los padres de familia mexicanos [. . .] exigen que la educación no sea ni obligatoriamente religiosa ni obligatoriamente laica; que se ajuste a las convicciones de los propios padres para que haya continuidad entre lo que se aprende en el hogar y lo que se enseña en la escuela, continuidad que es propia de los países auténticamente democráticos; que la educación institucionalizada tenga un fuerte contenido ético a nivel de valores humanos; que la educación no sea un instrumento de lucha de clases, sino de solidaridad y de preservación de la auténtica cultura nacional, que se respete esta opción de libertad que es la Escuela Privada, y que se apoye a los padres de familia haciendo deducibles los gastos educativos, hasta un determinado nivel. ${ }^{1}$

Sin embargo, a esta nota responde Carlos Monsiváis en la misma revista diciendo que las afirmaciones del adoctrinamiento comunista en las escuelas públicas solo buscaban suscitar pánico en la sociedad y ensalzar los alcances de las escuelas privadas (las cuales, sin embargo, no podían demostrar el grado de "perfección" que predicaban), denigrando clasistamente los de las escuelas publicas. Además, las acusaciones sin pruebas, de que los LTG imponían una concepción del universo y de la vida pansexualista, atea y filomarxista estaban muy lejos de la realidad, pues México seguía siendo constructor y reforzador del capitalismo.

En 1988 la CONALITEG había acumulado una deuda con la productora e importadora de papel Pipsa de 19524 millones de pesos que se sumaban a otros 20 000 millones de pedidos no pagados. La gran deuda hizo que la productora cortara el suministro de papel, lo que alegró a la derecha, que vislumbró el fin de los LTG. El cuestionamiento del sector empresarial sobre la utilidad de los LTG fue un tema constante en las reuniones con el para entonces candidato a la pre-

1 La libertad de enseñanza: derecho a decidir por los hijos (1984). Proceso, 390, 22-23. https:// www.proceso.com.mx/138478/la-libertad-de-ensenanza-derecho-a-decidir-por-los-hijos (Consultado el 02.07.19) 
sidencia Carlos Salinas de Gortari. Sin embargo, la mitad de la deuda con Pipsa fue pagada en octubre de ese año y se normalizó la impresión de los libros.

\subsection{La construcción de los modelos cognitivos de IDENTIDAD NACIONAL en la tercera generación de libros de texto}

Como hemos apuntado, esta generación de LTG no fue producto de una reforma educativa, por lo que se afirma que los cambios hechos a los libros de primero $\mathrm{y}$ segundo solo fueron de tipo formal y no de contenido (Salcedo Aquino 1982, p. 45). Sin embargo, aun cuando hemos reconocido los siete modelos cognitivos de la generación anterior, también hemos detectado que el énfasis que se les ha dado, la manera de conceptualizarlos, así como el orden en que fueron expuestos, cambió. Por esta razón, el MCI de MEXICANo es distinto del construido en las generaciones anteriores. Los siete modelos cognitivos que componen este MCI fueron apareciendo en el siguiente orden: el FENOTIPO, la CULTURA, la FAMILIA, el CIVISMO, el OTRO, el PAÍS y la HISTORIA NACIONAL.

\subsubsection{El modelo del FENOTIPO}

Las generaciones de LTG hasta ahora analizadas aquí han expuesto sus contenidos tomando en cuenta los intereses del niño de acuerdo con la edad en que idóneamente inicia la educación primaria, es decir, a los seis años. Tanto la generación de los sesenta como la de los setenta inician evocando en el lector la experiencia infantil, su reconocimiento como yo-niño, pero, mientras que la primera generación adopta un tono más serio para hablar de los deberes del niño hacia la familia, la sociedad y la patria, los manuales de diez años después nunca pierden el tono lúdico y relajado para tratar tales temas. Los libros integrados de los ochenta, en cambio, no enfatizan tanto el juego, pero también utilizan una gran cantidad de fotografías de niños para ilustrar los temas. De la misma manera que sus antecesores, las primeras páginas promueven el reconocimiento del lector dentro de la categoría niño.

El primer módulo titulado "Yo" presenta una serie de fotografías de niños y niñas de características similares: son morenos, tienen el pelo y los ojos oscuros, tienen alrededor de seis años y todos están vestidos de manera citadina. Este módulo pretende que el lector se reconozca como niño, pero, al mismo tiempo, se presenta un fenotipo con el cual se debe identificar. El tono de piel de los niños que aparecen en muchas de las fotos tiende a no ser tan claro (Fig. 3). 

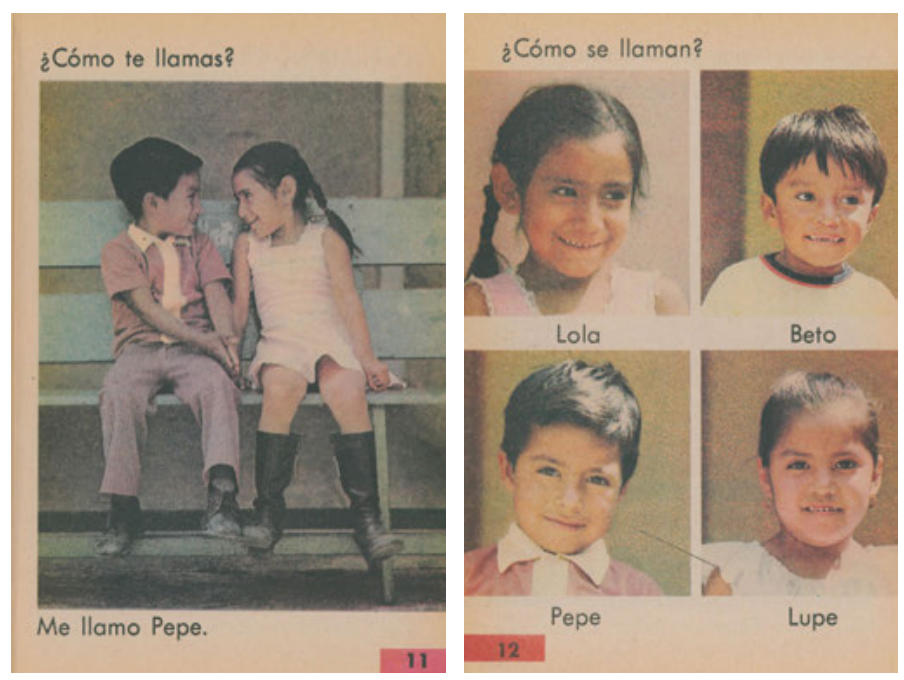

Fig. 3: Modelo del FENOTIPO (MLP I, pp. 11-12).

Sin embargo, cuando la parte verbal alude al yo o al nosotros se usa un fenotipo de piel más clara (Figs. 4 y 5). En estos textos los productores de los libros posicionan al lector en las mismas coordenadas situacionales que el hablante, es decir, los niños y las niñas de las fotografías. Estas figuras fungen como el centro deíctico que invita al lector a concebirse como parte de él ("Los que nacimos aquí somos mexicanos” MLP II, pp. 382-383). Sugieren una conceptualización subjetiva (Langacker 1987) (aquí, soy), provocando que el espectador se conciba dentro de la escena y se relacione con la representación visual que se le presenta ("Soy un niño. Soy una niña") (MLP I, pp. 14-15).

Así como los libros de los setenta expresan explícita y visualmente cómo son los mexicanos (Fig. 13, cap. 5), estos libros también lo hacen. Sin embargo, en contraste con los anteriores, que alejaban al lector del fenotipo mediante la implicación del ellos en "¿En qué se parecen estos niños? Todos son mexicanos" (CS, pp. 12-13), esta generación acerca, incluye e invita al lector a identificarse con las fotografias.

En el módulo "Somos mexicanos" queda establecido el prototipo físico del mexicano. En efecto, a partir de la relación entre la composición visual, que cubre dos páginas, y la verbal, que reza "Los que nacimos aquí somos mexicanos” MLP II, pp. 382-383), se propone el modelo idealizado del FENOTIPO (Fig. 5).

El espacio visual está compuesto por 20 fotografías rectangulares de niños y niñas tomadas en primer plano y acomodadas en forma piramidal. Con excepción del niño de tez más morena que se encuentra centrado y es un poco más 


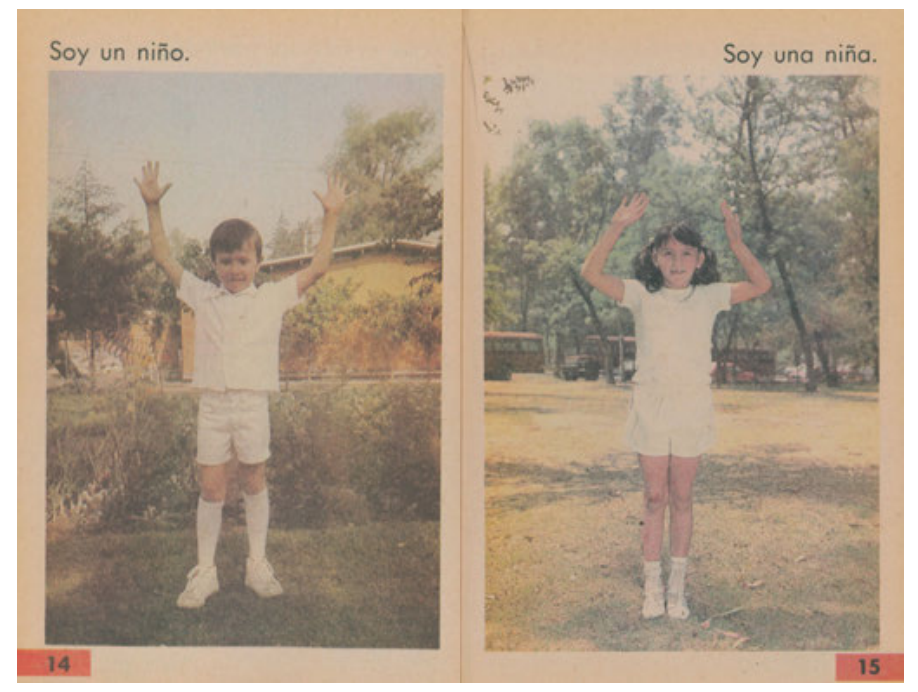

Fig. 4: Fenotipo elegido para designar al yo-niño (MLP I, pp. 14-15).

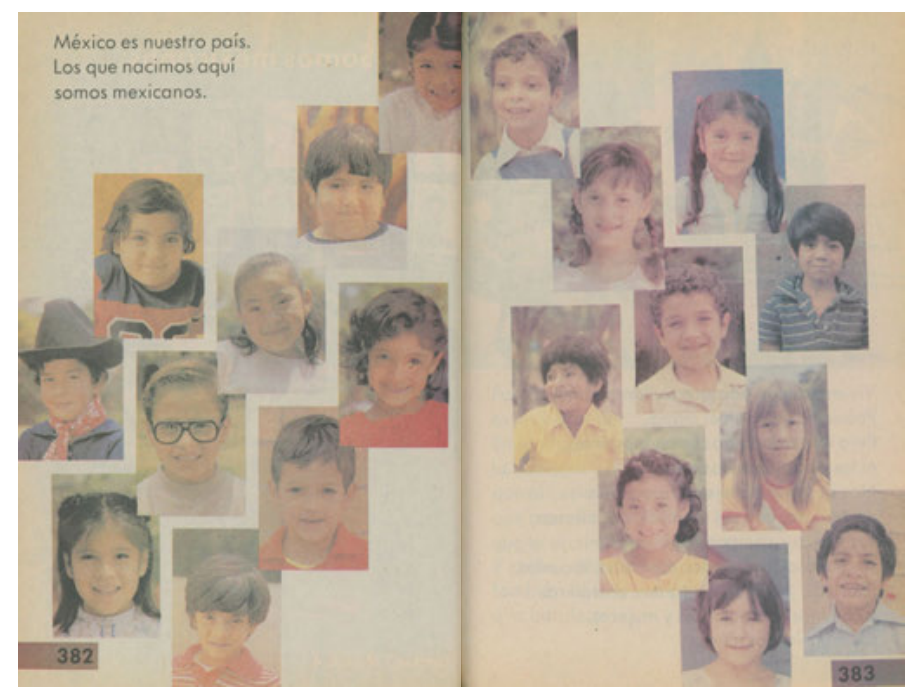

Fig. 5: Fenotipo del MCI de MEXICANO (MLP II, pp. 382-383).

pequeño que las demás figuras, los 19 niños restantes son representaciones demanda cuya mirada y sonrisa invitan al espectador a identificarse con ellos. Estas 19 figuras muestran características específicas: son niños de tez morena 
clara, de pelo oscuro, oscuro claro o incluso rubio; ojos oscuros y todos están vestidos de manera citadina. Así, estos libros promueven el ideologema:

- "Los mexicanos somos muy parecidos físicamente: nuestro color de piel es moreno claro".

\subsubsection{El modelo de la CULTURA: las tradiciones, los festejos, la comida y la educación}

El modelo CULTURAL es uno de los modelos que tiene más ocurrencias (51 oc.) y está conformado por cinco submodelos o instanciaciones: las celebraciones tradicionales ( 16 oc.), la música ( 3 oc.), la comida mexicana ( 29 oc.), la educación ( 2 oc.) y la lengua (1 oc.).

Los manuales hacen referencia a algunas tradiciones y celebraciones mexicanas. Por ejemplo, entre las lecturas se presenta una calavera literaria (Fig. 6), que es una composición en verso escrita como parte de la tradición del Día de Muertos. Este tipo de poemas populares se distingue por el tono burlesco y pícaro que ha sido usado desde su origen en el México Virreinal para hacer crítica social aludiendo a la muerte a través de personajes como la Catrina. Actualmente, estas composiciones tienen el objetivo de divertir y reírse de la muerte $o$ son dedicadas a un conocido donde se le advierte de manera jocosa que "la calaca”, "la flaca”, "la huesuda”, etc., va a venir por él/ella. Esta tradición, para muchas culturas incomprensible y quizás tenebrosa, se presenta de tal manera que no causa ningún miedo, ya que no evoca marcos cognitivos negativos, por el contrario, se activan los marcos de la DIVERSIÓn con la alusión de la flacura como algo irrisorio, y con palabras como traviesos y carnaval. Además, las imágenes que acompañan la lectura son calaveras de azúcar (dulce tradicional preparado para el Día de Muertos) que activan también el marco de la INFANCIA perfilando en él el concepto de golosina.

Otra tradición que se presenta en los manuales es la de romper piñatas. Como se puede observar en la Fig. 7, la composición visual y el texto activan los marcos de la comida (gordas calientes es un tipo de tortilla de maíz gruesa), de las GOLOSINAS (cacahuates) y de la DIVERSIÓN. Este último es activado mediante la imagen que representa una fiesta infantil donde los niños dibujados tienen una gran sonrisa (con excepción del niño que golpea la piñata). El acto volitivo que implica el último verso crea la inferencia que la acción de romper la piñata tiene más valor que los metales preciosos y por lo tanto es más deseable.

El carnaval como parte de las tradiciones mexicanas aparece como tema de una de las lecturas (MLP II, pp. 472-473). Un narrador desconocido hace la descripción de lo que se vive en la festividad y cuenta una situación concreta ocu- 


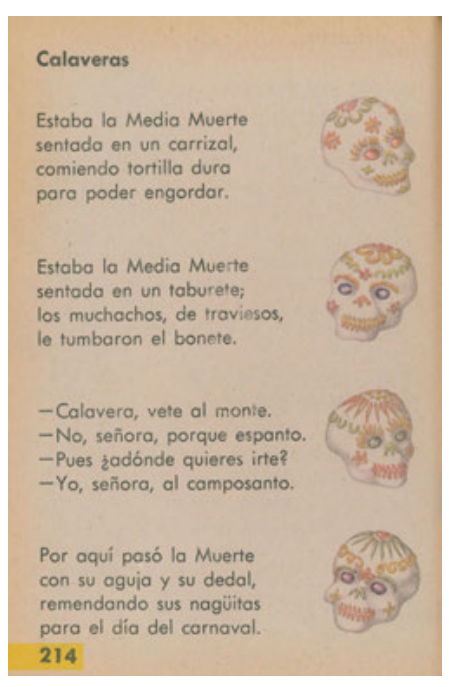

Fig. 6: Modelo CULTURAL: la tradición del Día de muertos (MLP I, p. 214).

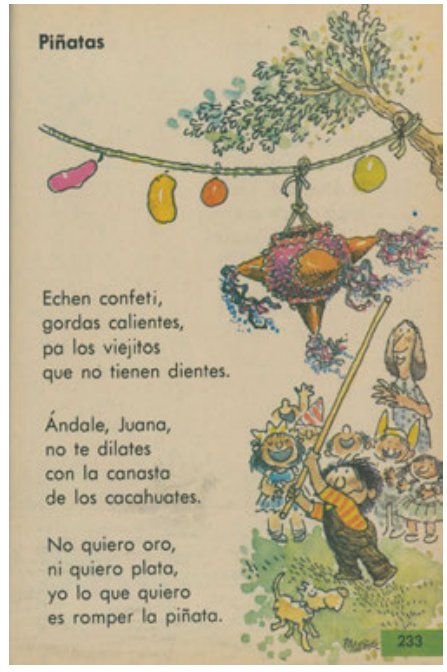

Fig. 7: Modelo CULTURAL: la tradición de romper la piñata (MLP I, p. 233).

rrida durante el festejo. La oración con la que inicia la lectura, "Los antiguos mexicanos celebraban sus fiestas con bailes y disfraces", activa el marco de los ANTEPASADOS, lo que provoca se evoque el marco de la TRADICIÓN. A pesar de que estos antepasados son conceptualizados lejos del centro deíctico (ellos, sus fiestas), esto sirve como anclaje para hablar del presente en que el sujeto de la enunciación es un nosotros: "Ahora también tenemos fiestas. Una de ellas es el carnaval. Lo festejamos todos los años durante cuatro días”. El marco de la DIVERSIÓN que ya se había activado a partir de las voces celebraban, fiestas, bailes, disfraces, festejamos se vuelve un espacio mental también forjado por el marco de la DIVERSIÓN/ALEGRÍA pero en el que aparece como sujeto un todos que hace referencia al nosotros de la frase anterior: "Todos andan alegres: cantan, bailan, se ponen disfraces y fingen combates”. Este espacio mental se visibiliza a través de la imagen de la lectura donde se representa con colores muy vivos una fiesta popular (Fig. 8). El marco de la DIVERSIÓN/ALEGRíA se mantiene abierto durante la descripción de la escena (celebrar, colores, chistes, se ríe) y de la narración de la travesura que planea y realiza uno de los niños protagonistas del evento: "Él los alcanza y ipam! los cascarones truenan”. La utilización de la interjección hace más detallada la narración sumándole audición a lo visual y le brinda un tono infantil a la narración.

Los manuales citan otras celebraciones solo a partir de fotos (una fiesta/ baile popular; unos Quince años; una comida familiar con un grupo musical to- 


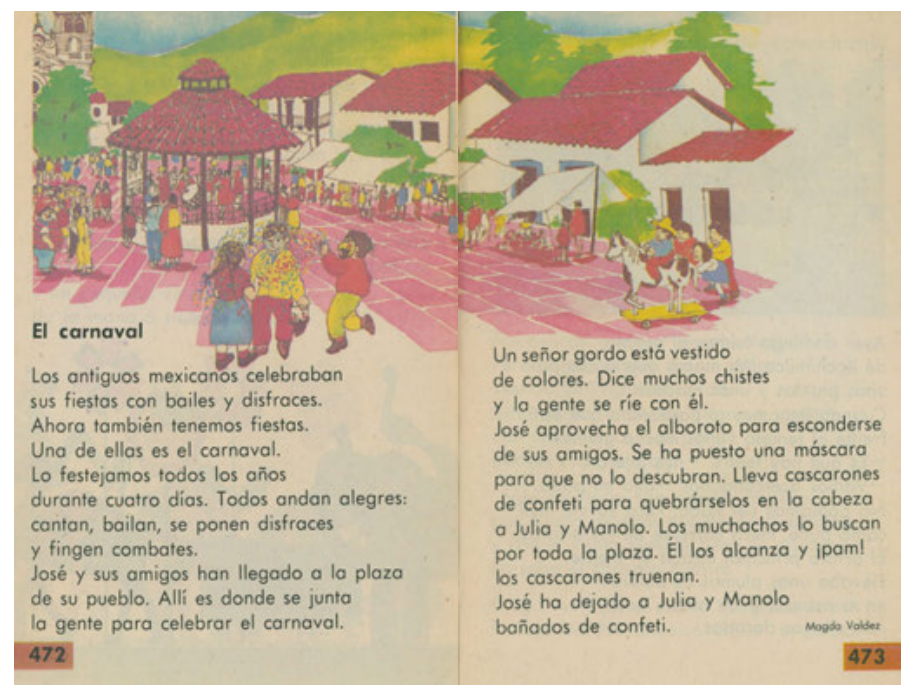

Fig. 8: El Modelo CULTURAL: la tradición del carnaval (MLP II, pp. 472-473).

cando al fondo; una mujer con características indígenas peinando a otra de trenzas - quizás para ir a una fiesta-; un rodeo) (MLP II, pp. 352-353). No se nombra el tipo de festejo que representa cada foto, pero se le pide al lector que responda a las preguntas “¿Qué crees que festejan estas personas? ¿Cuáles de estas fiestas conoces?”. Aunque en las fotos no se aprecian bien los rostros que indican alegría, las palabras festejar y fiestas evocan el marco de la DIVERSIón, dentro del cual se conceptualizará la última pregunta que cierra el módulo “¿Qué costumbres hay en tu comunidad?”, quedando así las costumbres dentro de este marco.

La última tradición que se cita en estos libros es la celebración del día de la Independencia de México. La lectura que hace referencia a este festejo (MLP II, pp. 464-466) es exactamente la misma que aparece en la generación anterior, con la única diferencia que cambiaron todas las imágenes que la ilustran (ver Fig. 24, cap. 5). Como apuntamos en el capítulo anterior, la lectura comunica el efecto emotivo que representa para el niño narrador esta tradición. También demostramos que la narración se conceptualiza dentro del marco de la DIVERSIón y cómo dentro de este se perfilan los conceptos de alegría y emoción.

La música es otra de las instanciaciones del modelo de la CULTURA y está muy ligada a las celebraciones tradicionales ( 3 oc.). En las fotos del tema sobre las costumbres mencionado arriba (MLP II, pp. 352-353) se pueden ver músicos vestidos de manera tradicional acompañando la fiesta. Pero también aparecen agrupaciones musicales tradicionales para ilustrar el módulo "Cómo suena y dónde está” (MLP I, p. 43) y el tema “Los servicios” (MLP I, p. 181) (Fig. 9). 
La fotografía de la izquierda, donde aparece un grupo de mariachis sobre una trajinera, adquiere gran relevancia debido a su tamaño (cubre toda la página) y al hecho de que fue la imagen elegida para iniciar una nueva unidad y un nuevo módulo. Por lo tanto, el niño lector debe detenerse a observar la imagen para poder empezar a imaginar la temática de la unidad. Asimismo, esta imagen alude al tradicional paseo en trajinera sobre los calanes del lago de Xochimilco (Ciudad de México), que a su vez activa el marco de la FIESTA/DIVERSIÓN, ya que es costumbre hacer fiestas y reuniones familiares durante el paseo en trajinera, muchas veces acompañadas por músicos. La segunda foto muestra un quinteto de músicos que posan muy alegres con atuendos e instrumentos procedentes del estado de Veracruz. La parte verbal de esta imagen indica que la música es un servicio que se brinda en las comunidades de México.

La comida mexicana es una elaboración del modelo CULTURAL que no podía faltar en estos libros (29 oc.). También aquí se utilizan palabras propias del marco de la COMIDA MEXICANA junto con su representación visual para que los niños recorten y jueguen (tacos, tomate (LR I, p. 85) chiles, chayote (LR II, p. 141); reconozcan los olores y los sabores (cecina (MLP I, p. 39, LRI, p. 19); para que practiquen ciertos grupos silábicos recortando y jugando (cajeta, jícama) (LR II, p. 163) o para que practiquen la adición sumando lo que cuestan las especialidades culinarias que vende un carrito ambulante ("El arroz y la machaca cuestan . . . ", "El consomé y el mole cuestan . . .", "El arroz y la cochinita cuestan . . .” (MLP II, pp. 354, 355).
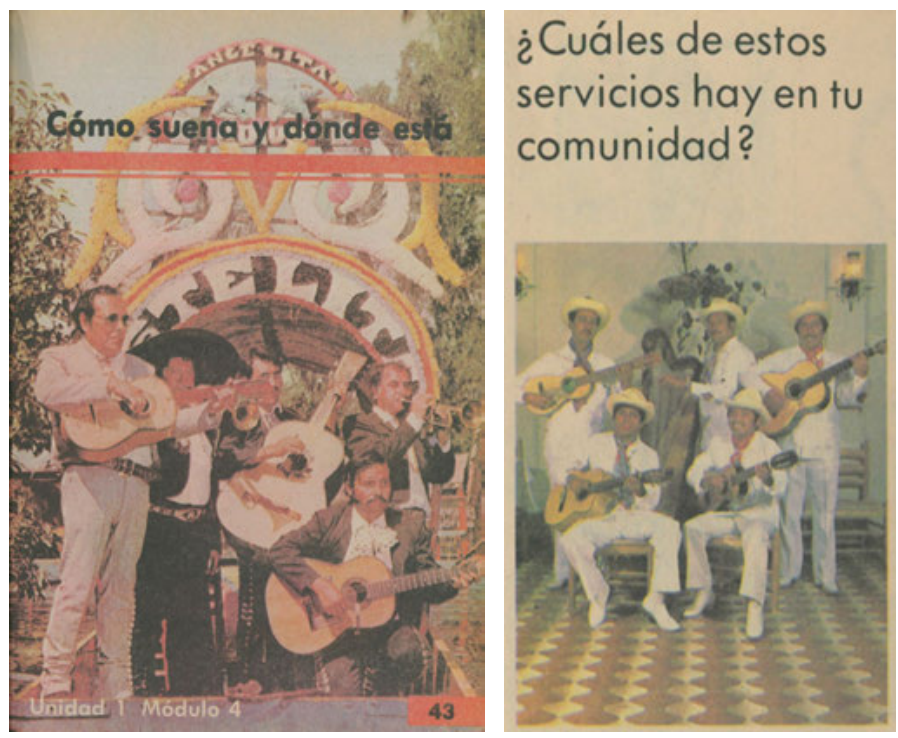

Fig. 9: Modelo CULTURAL: la música tradicional (MLP I, pp. 43 y 181). 
Una lectura muy significativa para nuestro análisis porque contiene explícitamente varios de los modelos cognitivos que conforman el MCI de MEXICANO es la titulada "Los mexicanos nos parecemos" (MLP II, pp. 388-389) (Fig. 10). Como el título lo indica, este texto presenta los aspectos que los mexicanos tienen en común. El marco cognitivo de la comida gana prominencia debido a que cierra la lectura y es uno de los dos marcos que puede ser representado visualmente a través de sus instanciaciones: los tacos, los tamales y las tortillas. La composición visual es más saliente que el texto porque abarca más de la mitad de las páginas. En esta escena transaccional de plano general, los tres participantes representados son colocados de perfil, por lo que no establecen una conexión imaginaria con el lector. Los tres son actores cuyos brazos y miradas forman vectores que apuntan hacia las instanciaciones a las que nos referíamos arriba: el niño señala hacia los tamales que están sobre la mesa y por extensión el vector llega hasta las tortillas que están cerca de ellos. Los brazos de la figura que representa la madre y su vista apuntan hacia los tacos. En la mano derecha sostine un plato con una cuchara. Podemos deducir que es la salsa picante porque este condimento pertenece al marco de los TACOS. La mirada de la niña y sus brazos apuntan hacia un libro, elemento perteneciente al marco de la EDUCACIón.

El texto, narrado en primera persona por un niño, comienza abriendo el marco cognitivo del TERRITORIO MEXICANO con la mención de dos pueblos del es-

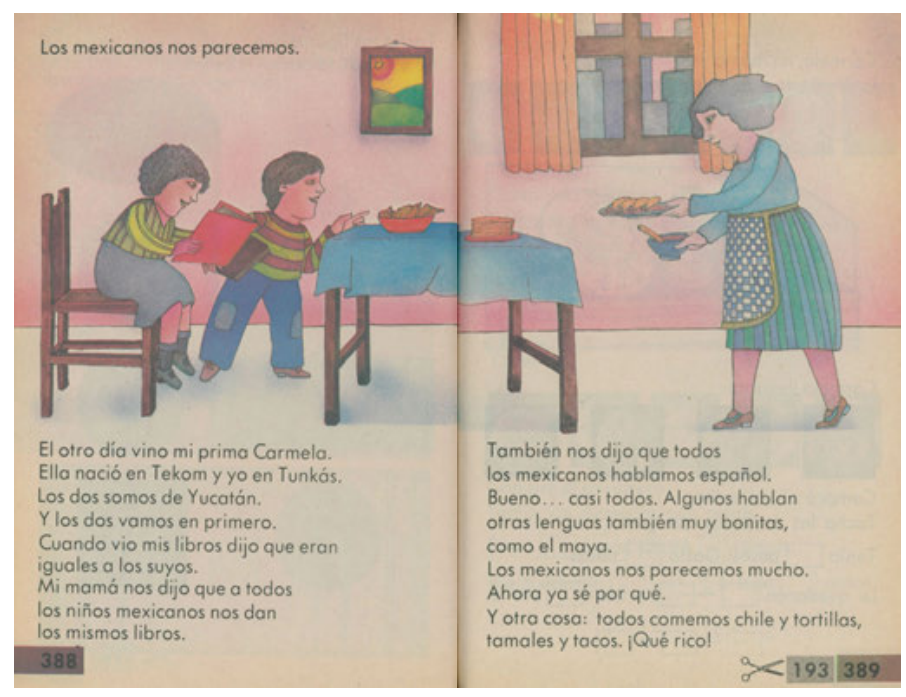

Fig. 10: Modelo CULTURAL y sus instanciaciones: la educación, la lengua y la comida (MLP II, pp. 388-389). 
tado de Yucatán, Tekom y Tukás, los cuales pueden representar cierta extrañeza y distancia para los lectores que no tienen familiaridad con la lengua maya. Inmediatamente después se activa el marco de la EDUCACIón a través de elementos que el niño lector reconoce perfectamente y que se atribuyen como aspectos que los niños mexicanos tienen en común:

(1) Y los dos vamos en primero. Cuando vio mis libros dijo que eran iguales a los suyos. Mi mamá nos dijo que a todos lo niños mexicanos nos dan los mismos libros.

La lectura hasta este punto ha abierto el modelo de la CULTURA, donde se procesará un nuevo marco, el de la LENGUA. El niño narrador parafrasea las palabras de la madre quien ancla al marco de la EDUCACIón instanciado por los libros, el de la lengua y afirma que los mexicanos comparten también este aspecto:

(2) También nos dijo que todos los mexicanos hablamos español. Bueno. . . casi todos. Algunos hablan otras lenguas también muy bonitas como el maya.

Además del marco de la LENGUA, este fragmento activa el modelo de EL OTRO, del que hablaremos posteriormente. Es decir, por un lado, evoca el marco de NOSOTROS LOS MEXICANOS, pero inmediatamente lo contrasta con el de ELLOS, LOS OTROS, al iniciar la siguiente frase con el marcador discursivo bueno con valor correctivo-reformulador y completarla con el adverbio de cantidad casi, con el que se hace una excepción y se saca del marco NOSOTROs a todos los que no hablan español. El hecho de que sea la madre quien hace esta afirmación tiene gran peso y validez para el niño lector, ya que, como la maestra, representa una figura de autoridad.

La lectura prosigue con la afirmación del niño narrador que funciona como la corroboración irrefutable de aquello que dijo la madre: "Los mexicanos nos parecemos mucho. Ahora ya sé por qué”. El texto termina con la activación del marco de la comidA: "Y otra cosa: todos comemos chile y tortillas, tamales y tacos”. El sujeto todos le da un sentido generalizador a la frase. Esta adquiere gran fuerza, por un lado, porque, como habíamos dicho, cierra la lectura, por otro lado, porque comienza llamando la atención del lector con "Y otra cosa". Esta estrategia genera la intuición de que lo que seguirá a continuación es algo adicional que no puede dejarse de mencionar. Finalmente, la expresión valorativa “iQué rico!” con que termina la lectura focaliza el gusto que los mexicanos tienen por su cultura culinaria. 
Así pues, los ideologemas relativos a la cultura que generan los manuales son:

- "Los mexicanos poseemos tradiciones que celebramos de manera muy alegre y somos felices de participar en ellas”.

- "Los mexicanos tenemos cosas en común como los libros escolares y la lengua”.

- "Los mexicanos hablamos español”.

- "A los mexicanos nos encanta la comida de México".

- “Todos los mexicanos comemos lo mismo".

\subsubsection{El modelo de la faMiLIA y sus componentes}

En los libros de los ochenta el modelo de la FAmiLia es mucho más elaborado y aparece con más frecuencia (111 oc..) que en la generación anterior (60oc.). Las figuras del padre y la madre se presentan al mismo tiempo de manera icónica en la unidad 2, módulo 1 "Lo que me gusta hacer" (MLP I, p. 65) (Fig. 11). Esta lección sobre los cuidados y necesidades del niño abarca dos páginas. Cada una de las fotos presenta una escena que contiene las respuestas a las preguntas "¿Qué necesitan los niños para crecer sanos y felices?, ¿Quiénes te cuidan?, ¿Cómo te cuidan?, ¿Por qué te cuidan?”. La primera página pretende activar los marcos cognitivos de la SALUD y la FELICIDAD, siendo este último el más relevante para el niño de seis años. En este marco se procesarán y almacenarán las informaciones sugeridas por las fotos, incluso aquellas de la siguiente página en donde aparecen los padres. El hombre y la mujer con los niños en brazos se conceptualizan fácilmente como los padres, ya que la parte textual los relaciona con el marco mental del CUIDADO DE LOS HIJOS. Abierto este marco, las imágenes perfilan los conceptos de amor y protección que se atribuirán a estos miembros de la familia.

Estos libros se diferencian de las antiguas generaciones porque intentan comunicar una paridad de género con respecto a los cuidados y responsabilidades hacia los hijos. En la Fig. 11 se puede constatar que la respuesta esperada a la pregunta “¿Quiénes te cuidan? ” es “mi papá y mi mamá”. Sin embargo, observando la imagen, la primera figura que viene a la mente es el padre debido a la colocación superior y de mayor tamaño de la foto que lo representa. Por lo tanto, se refuerza la propiedad protectora prototípicamente atribuida al padre. Esta propiedad se observa claramente en el módulo 2 "La familia" de la unidad 2 (Fig. 12). 


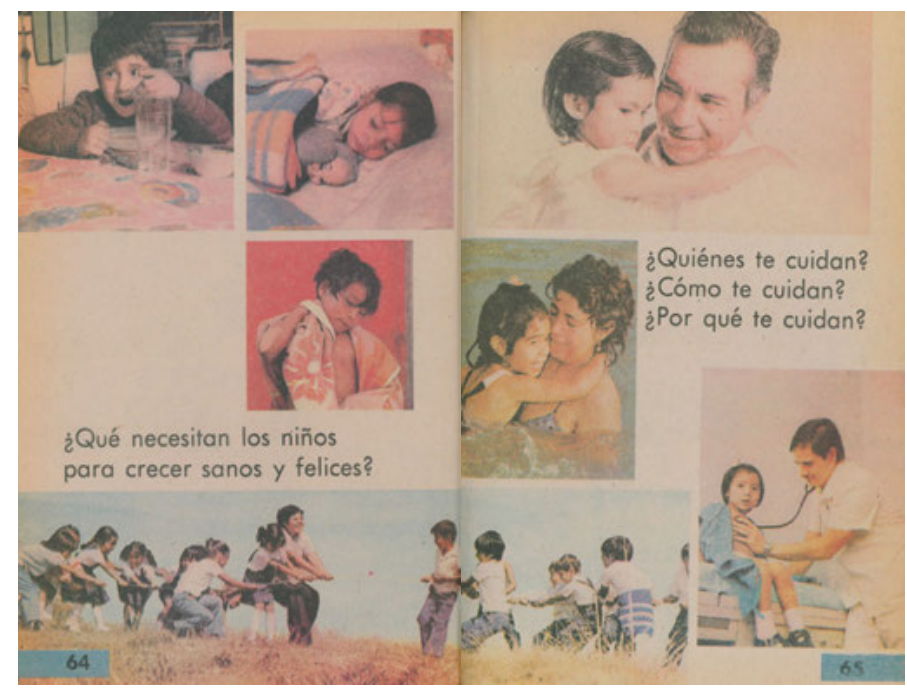

Fig. 11: El modelo de la FAMILIA: protección, amor y cuidados de los padres hacia los hijos (MLPI, pp. 64-65).

Como en el ejemplo anterior, en esta imagen el padre toma el lugar más prominente en la escena al ser colocado en la parte superior y central del espacio visual. De esta manera, los valores que evoca la figura remiten a lo ideal, lo bueno, lo más importante, el núcleo al que se supedita el resto de los elementos, en este caso los demás miembros de la familia. Los brazos de esta figura forman vectores que apuntan hacia las dos mujeres de la imagen, la madre y la hija, quienes se encuentran dentro del círculo que el padre forma con su cuerpo, lo cual brinda la sensación de protección. La figura materna, en cambio, dirige los brazos hacia el miembro más pequeño de la familia también indicando protección, aunque de manera un poco más distanciada. La imagen, pues evoca el marco de la PROTECCIÓN atribuyéndole esta característica principalmente al padre. La escena implica un proceso no transaccional donde las figuras están representadas de frente y observan directamente al lector. Esta angulación establece un total involucramiento con el lector y comunica la idea de objetividad, es decir, suscitan la aseveración "This is how it works" (Kress \& van Leeuwen 2006, p. 145). De este modo, el modelo FAMILIAR queda establecido. Por lo que se refiere a la parte verbal, esta activa directamente el marco del CARIÑo que es comprendido como parte del MCI de FAMILIA. Una vez abierto y fijado el modelo FAMILIAR, la página siguiente activa el marco cognitivo de la CASA. Así, el módulo hace que se relacione directamente a la familia con la casa y se vuelva esta parte del MCI como en los libros de la primera generación. 


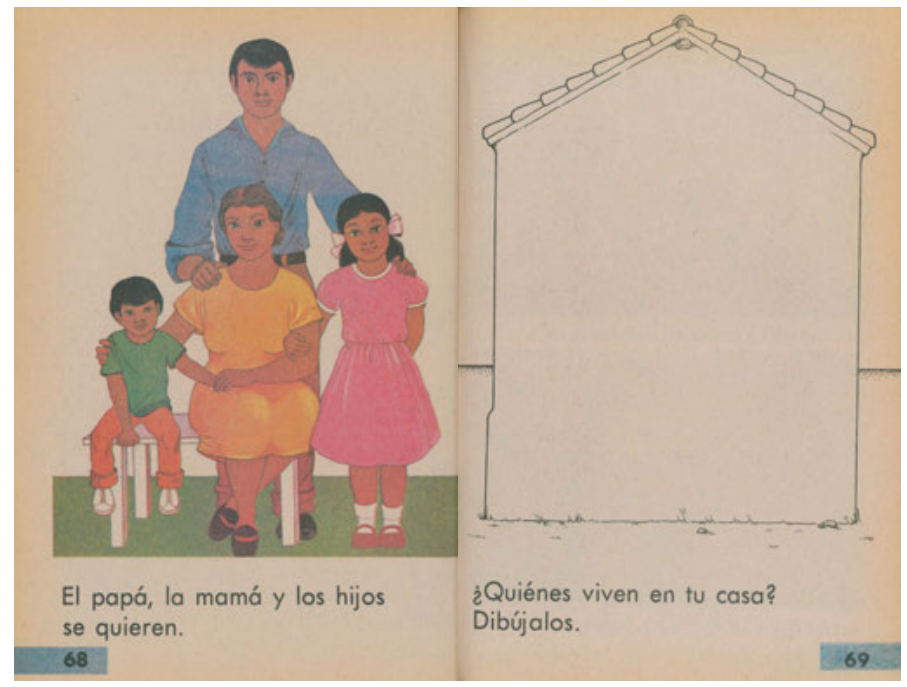

Fig. 12: El MCI de PADRE y su posición privilegiada en el espacio visual (MLP II, p. 68).

En el módulo "La familia" también aparecen fotos del padre y la madre cuidando el arreglo de los hijos y realizando actividades lúdicas con ellos (Fig. 13).

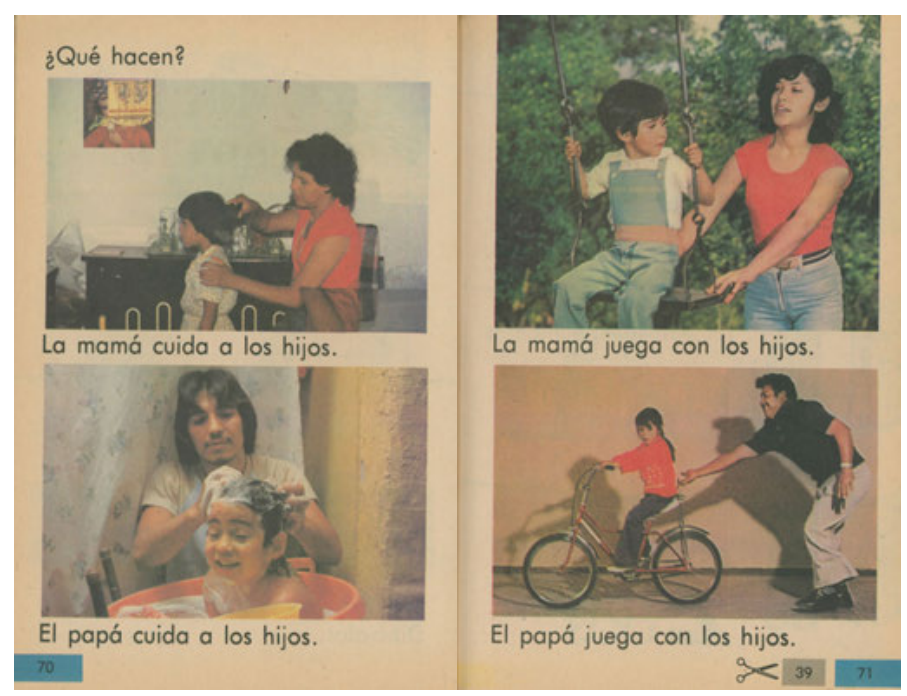

Fig. 13: La propiedad de cuidador de los hijos del MCI de MADRE según su colocación espacial (MLP I, pp. 70-71). 
La información que se desea transmitir es que la madre y el padre cumplen las mismas funciones con respecto a los hijos. Sin embargo, la colocación superior de la madre evoca la metáfora lo IDEAL ES ARRIBA, con lo que se comunica que esas funciones (el cuidado físico y las actividades lúdicas con el hijo) le pertenecen idealmente a ella. Esta información se refuerza en el libro recortable (LR I, p. 39) donde la madre adquiere prominencia al ser colocada a la izquierda del espacio visual (Fig.14).

En este caso, al ser ubicadas las imágenes de la madre y del padre, aparentemente al mismo nivel, se pretendía comunicar que la actividad que desempeñan (cuidados del hijo) es propia de ambos; sin embargo, la imagen de la madre y la actividad que realiza quedan en el lado de lo aceptable, lo familiar, en contraste con la figura del padre que queda en el lado de lo nuevo, por lo que se asume que esa actividad es más propia de la figura femenina. Además, cabe señalar que la información que ofrece la imagen es corroborada por la parte textual que incita al lector a evocar primeramente el MCI de MADRE. Esto se debe a que la primera oración de completamiento que el niño debe realizar y que implica la palabra mamá requiere un mayor esfuerzo cognitivo que la segunda en la que aparece la palabra papá, porque esta conlleva solo una operación de repetición; es decir, en la primera oración el niño tiene que pensar, apoyándose en la imagen, “¿quién cuida a los hijos?".

Raúl Ávila (2011, p. 397), coautor de los libros de Español de 1972 y coordinador general de los libros editados a partir de 1980 cuenta su experiencia en la elaboración de esta generación y confiesa que:

Los problemas que no se notan y las consecuencias de todo esto, para terminar, fueron, entre otros: el hecho de que cada página era no sólo un asunto pedagógico, sino también ideológico, político y cultural. Siempre nos preocupó el equilibrio de sexos -de géneros no, porque no hacíamos preguntas íntimas ni había estadísticas al respecto-. Un ejemplo de esto son las niñas, los niños y su porcentaje en los libros; admito que, según nuestras cuentas, ganaron los niños por 52 a 48. Para equilibrar el sesgo porcentual, las niñas ganaron el primer plano de la portada de segundo. En cuanto a labores, los dos hacían de todo y a veces las niñas eran -como es natural- más listas que los niños.

Como se puede observar de la cita, sí había una conciencia sobre la representación igualitaria de los dos sexos; sin embargo, como lo menciona Ávila, la cuestión del género no fue tomada en cuenta. En efecto, aunque parecería que los libros dan igual oportunidad de aparición al hombre que a la mujer y tratan de hacer entender que las responsabilidades de los padres hacia los hijos son las mismas, la conceptualización que surge de las composiciones visuales sigue asignando a la madre las tareas prototípicas del modelo de la CRIANZA. 


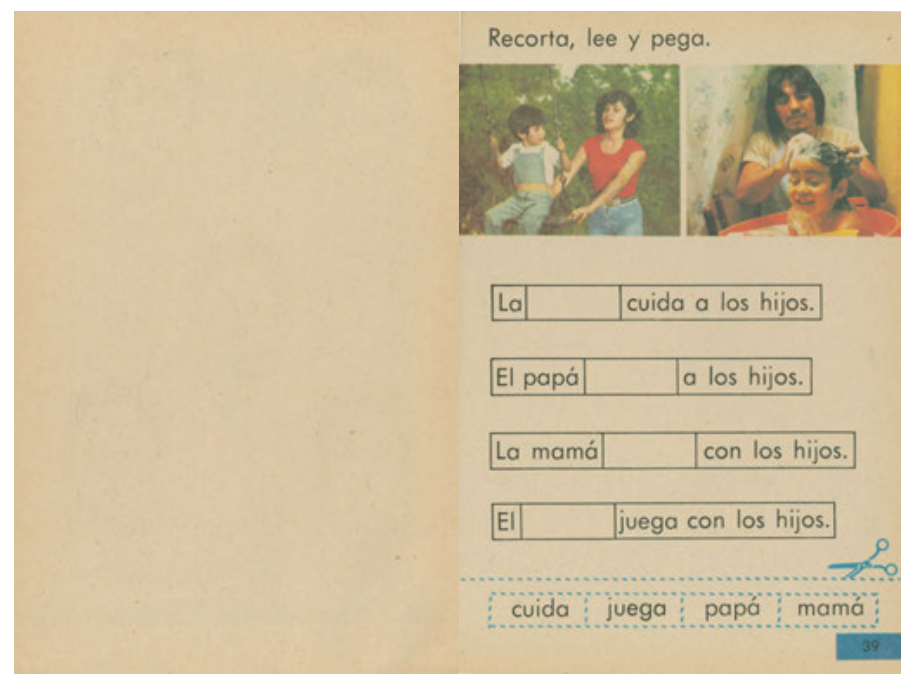

Fig. 14: La propiedad de cuidador de los hijos del MCl de MADRE según su colocación espacial (LR I, p. 39).

Esta generación de libros construye un MCI de MADRE mediante los modelos propuestos en la primera generación, algunos de los cuales habían perdido fuerza en la segunda. Por ejemplo, se asocia a la madre con la alimentación de la familia (5 oc.) y las labores domésticas (10 oc.). El modelo del NACIMIENTO es también mucho más claro y recurrente que en la generación anterior, pues hay más imágenes que muestran mujeres con bebés en los brazos (10 oc.). En cuanto al MCI de PADRE, persiste el modelo de la RESPONSABILIDAD en su aspecto educativo ( 4 oc.) pero, como hemos apuntado arriba, se agrega un valor: el cuidado físico del niño ( 4 oc.), valor compartido por primera vez con el del modelo de MADRE. Además, aunque ya no se haga referencia al dinero, se vuelve a asociar al padre con el trabajo fuera de la casa (7 oc.) como en el primer libro (a diferencia de que en este manual los oficios no solo son rurales como lo era la mayoría en 1960).

Otra peculiaridad de estos libros es que consideran a la familia compuesta por más de cuatro miembros: los hermanos (9 oc.), los tíos ( 2 oc.), los abuelos ( 5 oc.) y los primos (1 oc.) tienen lugar entre las lecturas.

Para finalizar, citamos los ideologemas que estos libros evocan con respecto a la familia:

- "Mamá es la persona que me dio a luz, me nutre y cuida mi estado emocional y de salud". 
- "Realiza actividades domésticas y es la principal responsable de mis cuidados".

- "Papá me educa y, al igual que mamá, se hace cargo de mi estado físico, pero en menor grado".

- "Papá tiene un trabajo y es el protector de la familia".

- "Los padres, los hermanos, los tíos, los abuelos, los primos conforman la familia”

\subsubsection{El modelo del CIVISMO}

El modelo del CIVISMo es el menos elaborado en estos libros (33 oc.). Tal como sucede en la generación anterior, las normas de comportamiento que el niño debe seguir no se adjudican específicamente a la sociedad mexicana. Se trata de tres normas de carácter universal: la limpieza (3 oc.), por ejemplo “¿Dónde se pone la basura?” (MLP I, p. 85); el aseo personal, cuyas ocurrencias (16 oc.) se incrementan a partir de las modificaciones de 1978, pues, como ya se dijo, se agrega el área programática de la educación para la salud: "Me lavo los dientes. Me lavo las manos. Me lavo la cara” (MLP I, p. 98), “¿Por qué se deben lavar las manos antes de preparar los alimentos? ¿Qué alimentos se deben cocer?” (MLP II, p. 288). La tercera instanciación cívica es la ayuda en su sentido de colaboración (14 oc.): "Los hijos ayudan. -Mamá, queremos ayudarte. Tenemos una idea. -Son muy listos” (MLP I, p. 76); "Yo ayudo a mi papá a traer leña” (PLM I, p. 206); "En el pueblo van a construir una escuela. Todos los niños ayudan a cargar materiales” (MLP II, p. 258). Incluso el módulo 4 de la unidad 3 se llama así, "Colaboramos". Sin embargo, como se puede apreciar de las ilustraciones (Fig. 15), el marco mental que activan las fotografías es el del JUEGo y no hay nada que indique un comportamiento que tenga efecto en la sociedad específicamente mexicana. El resto de las imágenes de este módulo presentan un escenario escolar donde cada niño hace algo en el salón de clases o en el huerto.

Los ideologemas que surgirían de estas informaciones son:

- “Nos tenemos que asear".

- “Debemos poner la basura en su lugar”.

- "Para jugar necesitamos organizarnos".

- "Los niños tenemos que trabajar en conjunto en la escuela".

- “Ayudamos a nuestros padres". 

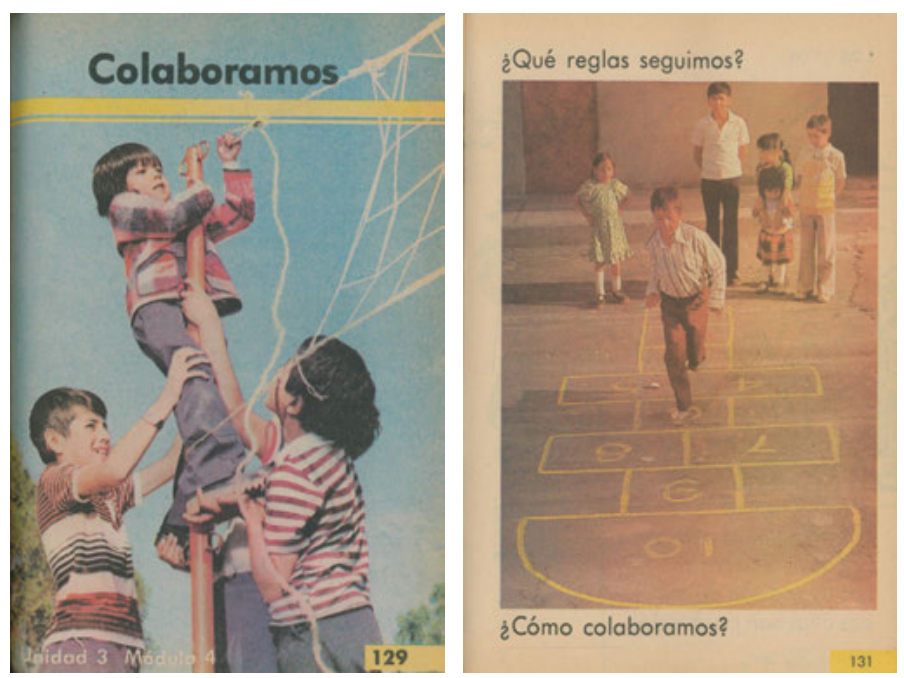

Fig. 15: El modelo del CIVISMO: la colaboración (MLP I, pp. 129 y 131).

\subsubsection{El modelo de EL OTRO: el indígena y el español}

El modelo de EL OTRO, es decir, el que queda fuera de la comunidad mexicana, está representado en los manuales por dos figuras: el indígena y el español. Estas figuras aparecen como en los primeros libros, pero a diferencia de estos, aquí la presencia del español es sutilmente mencionada y, en el caso del indígena, solamente sugerida a través de unas cuantas imágenes. En efecto, en los LTG de 1980 aparece en 9 ocasiones la imagen de personas que portan la vestimenta atribuida a los indígenas, pero el indígena o, como lo llamaban en los primeros libros, “el indio”, nunca es nombrado verbalmente, no tiene voz, solo aparece un dibujo, siete fotos y es aludido mediante el modelo de la lengua, como se explicó anteriormente.

La Fig. 16, último módulo de la unidad 5 "La colaboración entre el campo y la ciudad” (MLP II, p. 296), presenta un niño con la indumentaria prototípica del indígena: camisa y pantalón de manta, sombrero de paja y sandalias. El personaje, que en esta ocasión sí tiene nombre, Andrés, está abriendo un costal en un espacio totalmente rural. El texto de esta imagen "¿Qué trajo Andrés de la ciudad? Dibújalo” establece la oposición campo-ciudad, lejanía-cercanía. El dibujo es colocado en la parte inferior del espacio visual por debajo de otro dibujo de una niña dentro de su habitación, vistiendo ropa de ciudad y abriendo una maleta cuyo texto recita “¿Qué trajo Pilar del campo? Dibújalo”. La ubicación de las imágenes evoca las metáforas espaciales ARRIBA ES BUENO, ABAJO ES MALO 


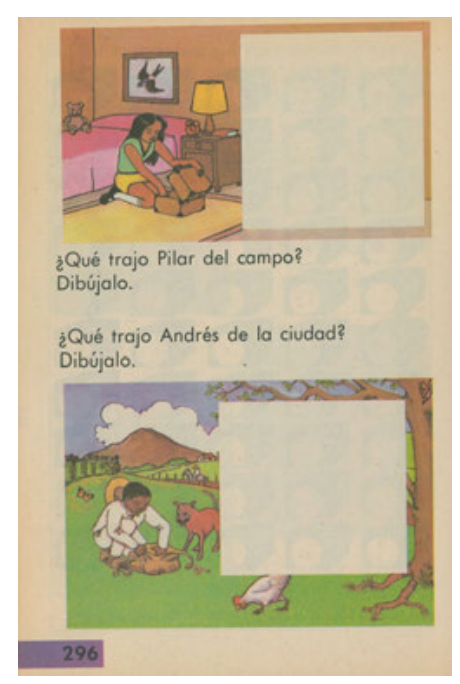

Fig. 16: El modelo de EL OTRO: el indígena (MLP II, p. 296).
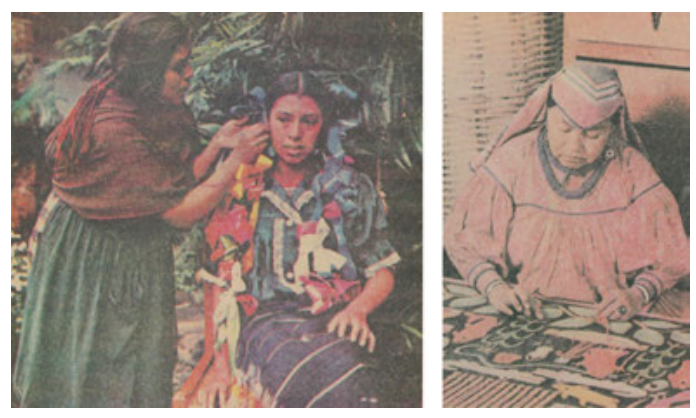

Fig. 17 y 18: Representaciones offer del indígena (MLP II, p. 353; MLP I, p. 155).

(Lakoff y Johnson, 1980, p. 51), por lo que Andrés y su espacio adquieren las propiedades menos aceptadas que la figura de Pilar y su espacio.

Las cinco fotos en las que aparece gente indígena son representaciones de tipo ofrecimiento donde los participantes no establecen ninguna conexión con el lector, son solo objeto de observación (Figs. 17, 18 y 19). En las demás fotos las figuras están de perfil, o no se les ve el rostro y se encuentran en un tercer plano, muy alejadas del lente de la cámara. Todo lo anterior implica distanciamiento con el observador y una completa desubjetivización.

En la Fig. 19 se puede ver cómo a pesar de que la palabra vecinos perfila acercamiento, cuando aparecen las fotos de gente con ropas indígenas se aleja la toma y se coloca a estas personas en la parte inferior del espacio visual o simplemente no se les deja ver el rostro. Todo lo contrario sucede con las figuras utilizadas para ilustrar el inicio del módulo 2 (unidad 6) "Los vecinos", donde los participantes representados abarcan toda la página (plano entero), lo cual les da una prominencia alta (Fig. 20). Además, su fenotipo corresponde al que fue establecido para el MCI de MEXICANO. Así, la imagen comunica que los vecinos ideales tienen estas características.

En la última foto (Fig. 21) en la que se pretende retratar a los grupos indígenas no se observan personas sino maniquíes sin rostro y con indumentaria indígena. La imagen, tomada en plano general, pertenece a la unidad 8, módulo 4 


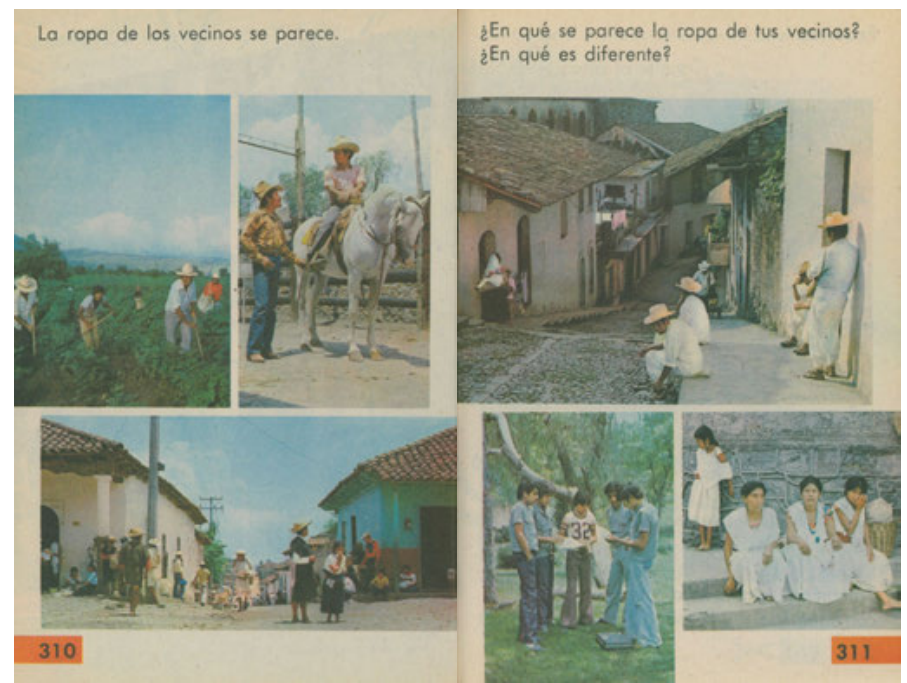

Fig. 19: Distanciamiento emotivo que representa el indígena (MLP II, pp. 310-311).

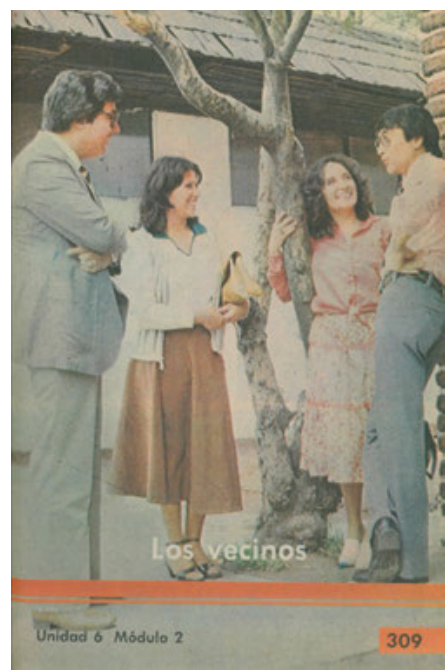

Fig. 20: Acercamiento emotivo e identificación con el fenotipo idealizado del mexicano (MLP II, p. 309).

“México y su pasado” y se encuentra por debajo de figuras pertenecientes a culturas prehispánicas.

La composición visual que comprende dos páginas advierte verbalmente que "Guardamos cosas para recordar [. . . ] Las exponemos en los museos" (MLP II, pp. 431-432). A partir del título del módulo se activa el marco del PASADO y la 
parte verbal hace que se perfile el concepto de museo y nociones asociadas como lo antiguo, lo que ya no existe, pero vale la pena recordar. De esta manera, el indígena es introducido en la categoría de folklor, de algo "valioso" pero que ha quedado en el pasado y no pertenece a la modernidad.

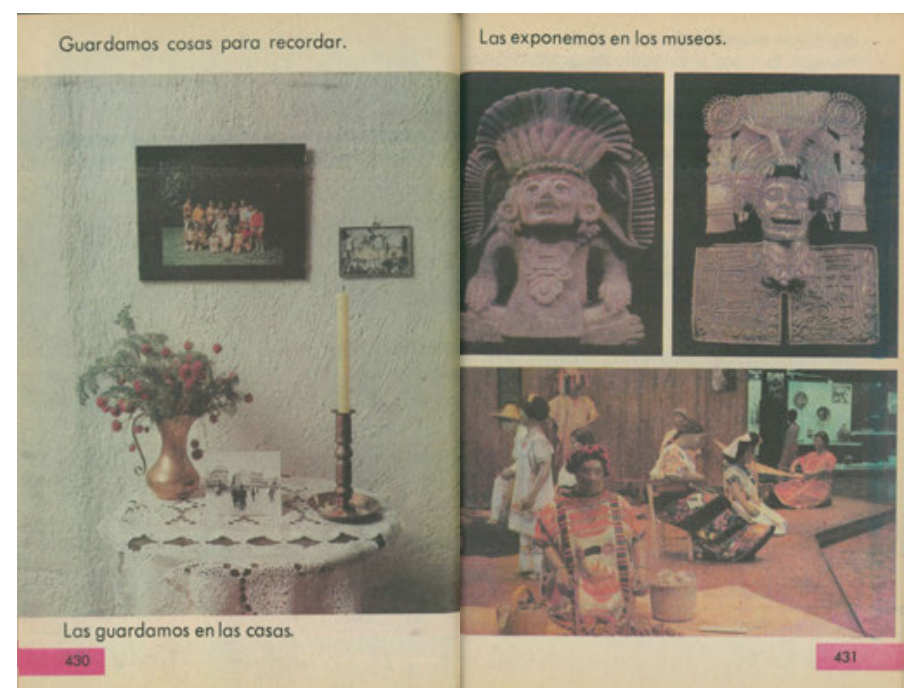

Fig. 21: El indígena como instanciación del pasado de México (MLP II, pp. 430-431).

El segundo otro, el español, es aludido 5 veces y también es desubjetivizado, ya que se hace referencia a él mediante una pintura (aparecida 2 veces) de una catedral colonial que va acompañada de los textos "Cuando llegaron los españoles, hicieron otros edificios. México cambió mucho" (MLP II, p. 438) (Fig. 22) y "La ciudad de los españoles” (LR II, p. 223).

Si tomamos en cuenta que la página precedente dice "Los aztecas fundaron México-Tenochtitlan en un lago. La ciudad era muy hermosa. Tenía palacios, templos y muchos canales” (MLP II, p. 437), y en la siguiente página se expone "Cuando llegaron los españoles, hicieron otros edificios. México cambió mucho" (MLP II, p. 438), se puede inferir que estos últimos acabaron con la belleza de la ciudad, ya que no se utiliza ningún calificativo para las construcciones españolas.

En el libro recortable se vuelve a hacer alusión a la cultura española en contraposición a la azteca (Fig. 23).

Como se puede observar, la saliencia que se les da a los aztecas ya no es a partir de calificativos como en el libro de lecturas, sino a través de la disposi- 

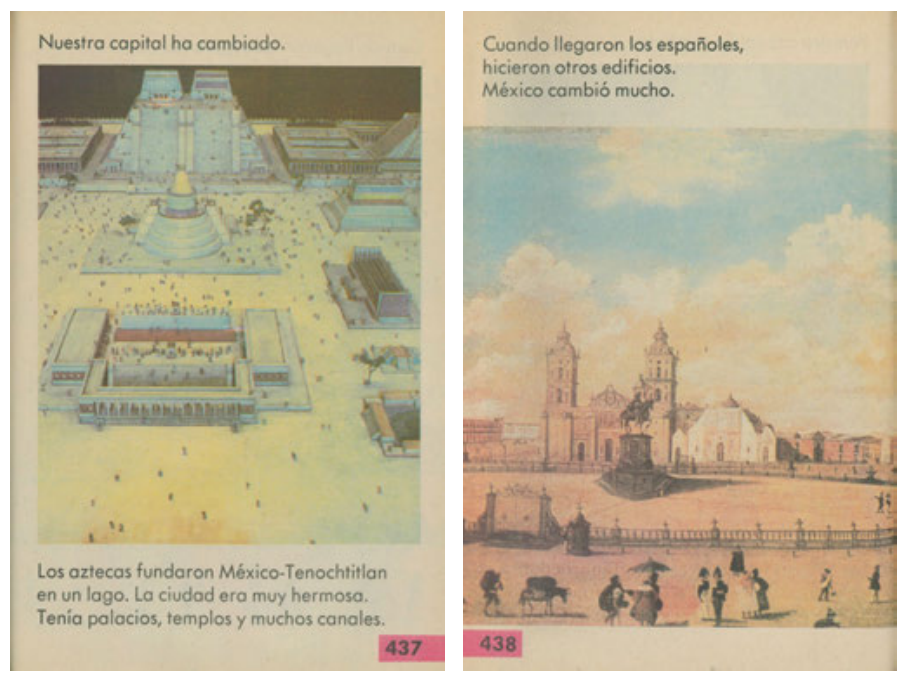

Fig. 22: Modelo de EL OTRO: el español en contraposición al mundo prehispánico (MLP II, pp. 437-438).
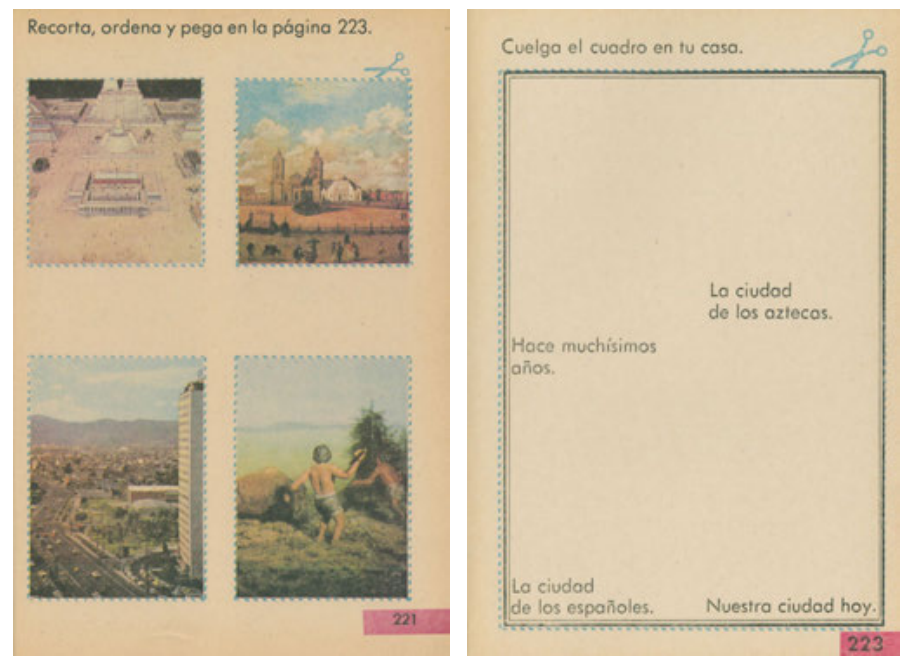

Fig. 23: Creación de distanciamiento hacia el mundo español y acercamiento al azteca (LR II, pp. 221, 223). 
ción espacial de la imagen de su ciudad. En la página para recortar, esta aparece del lado de lo conocido, mientras que la ciudad española se encuentra en el lado de lo extraño. Además, la imagen de la ciudad azteca es presentada en picado, en una toma de arriba hacia abajo, con lo que el observador adquiere poder sobre la figura. La siguiente página es el soporte de lo que será un cuadro que deberá ser colgado en la casa de los niños según las instrucciones. En la parte superior se debe pegar la ciudad azteca y en la inferior la española. Aunque en ambos casos se percibe un distanciamiento porque se habla de la ciudad de ellos, la disposición espacial de la imagen que activa el marco del mundo prehispánico; el tipo de toma que presenta; la referencia que se hace en el libro de lecturas al nosotros con "Nuestra capital"; y la colocación de la palabra México como parte del topónimo "México-Tenochtitlan" hacen que el escolar asuma que la cultura azteca le pertenece, mientras que los españoles resultan los extraños, los otros, los que terminaron con la belleza de algo que es suyo.

La última foto en la que se alude al español, también hace referencia al indígena (Fig. 24). Esta representa una metáfora visual de la fusión de los mundos y de la idea del México actual que los LTG quieren comunicar. La foto fue tomada desde lo alto (picado). En ella se aprecia un lugar de México (Tlatelolco) donde se ven, en un primer plano, ruinas arqueológicas prehispánicas, en un segundo plano una iglesia colonial y, como fondo, varios edificios altos que representan la modernidad.

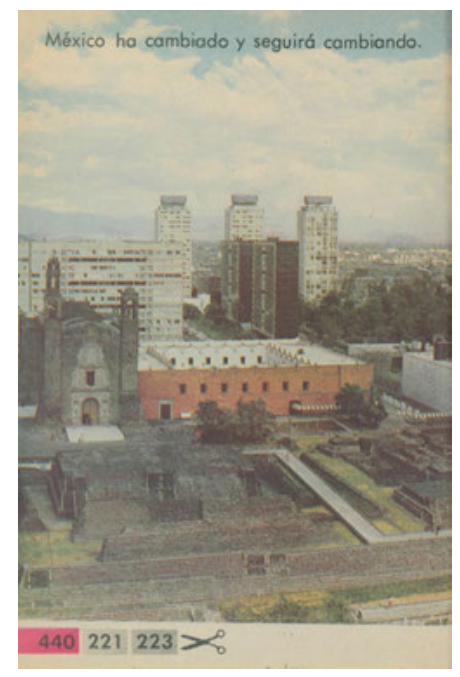

Fig. 24: Representación del México actual: la fusión cultural y la modernidad (MLP II, p 440). 
Así las cosas, los ideologemas que promueven los libros con respecto al indígena - que en estos libros no son lo mismo que los aztecas, es decir, quedan fuera del marco de los GRANDES IMPERIOS PREHISPÁNICOS- y al español son:

- "Hay otros que no son como nosotros, son extraños, viven lejos y no nos podemos comunicar con ellos”.

- "Lo indígena es folklor, es parte del pasado".

- "Los españoles acabaron con la majestuosidad de la ciudad azteca”.

- "El pasado de México comprende la fusión del mundo indígena y el español, pero en la actualidad es un país moderno”.

\subsubsection{El modelo de Méxıco en términos de territorio, pero con matiz nacionalista}

Uno de los cambios que sufrieron los libros de los ochenta, y que resulta muy relevante para este estudio, es la aparición de una unidad (unidad 8) en la que se concentran muchos de los modelos que conforman el MCI de IDENTIDAD MEXICANA. Esta unidad concluye con el módulo 4 "Somos mexicanos", el cual evoca varios modelos cognitivos: el del FENOTIPO, del que hablamos páginas atrás (Fig. 5); el modelo del NACIMIENTO: "Los que nacimos aquí somos mexicanos” (MLP II. pp. 382); el modelo de la LENGUA ESPAÑOLA, de la COMIDA y del OTRO, de los cuales hablamos también anteriormente (Fig. 10). Asimismo, en este módulo aparece la lectura titulada "La bandera" que figura en el libro de Español de la generación anterior (EE. pp. 219-220), con la diferencia de que todas las imágenes son nuevas (Fig. 25).

Como habíamos mencionado, en esta lectura se categoriza a México como un país. Dicho modelo se construye a partir de seis marcos cognitivos, a saber, el de la CASA/VIVIENDA: "Vivimos en un país que se llama México"; el marco de la EXTENSIÓN TERRITORIAL: "Podemos verlo en el mapa”, "México es muy grande”, y el modelo de la GEOGRAFÍA, que genera la imagen de variedad y riqueza natural. Pero además, esta lectura activa el marco del CARIÑo dentro del cual quedará insertado México y su representante concreto, la bandera: "Y como a México le tenemos cariño, también le tenemos cariño a la bandera”.

En la versión de los libros de los setenta, la imagen que ilustra este texto es una bandera bidimensional que abarca un tercio de la página (Fig. 19, cap. 5). En contraste, en esta nueva versión el espacio visual abarca la mitad de las páginas y está compuesto por cinco fotografías. En cada una aparece al menos una vez la bandera mexicana. Las dos primeras fotos y la que está colocada al centro de la segunda página activan el marco INFANTIL perfilando el juego: en la primera imagen se ve la representación tipo demanda de una niña de cinco o seis años, de pie sobre un juego tubular giratorio, como en un pedestal soste- 


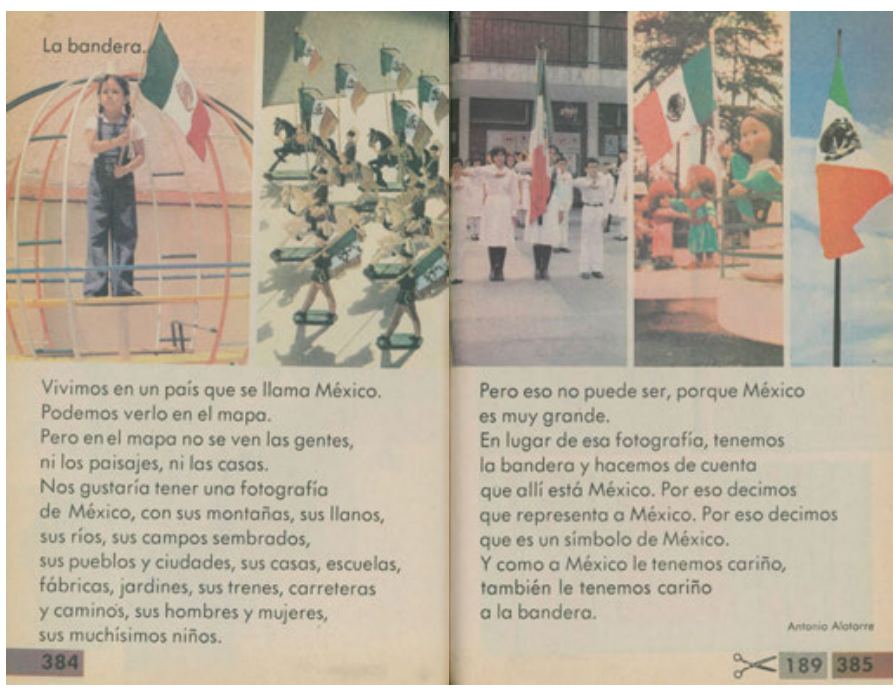

Fig. 25: Modelo de MÉxICO: nueva versión visual 1980 (MLP II, pp. 384-385).

niendo orgullosamente con las dos manos el asta de una bandera. La posición erecta, de frente y en alto de la figura infantil, además de la toma de plano entero que connota una distancia social corta, la colocación de la foto en la parte superior izquierda y su mayor tamaño, le brindan la mayor saliencia de la composición. A su derecha se encuentra la foto en plano largo y en picado de un grupo de ochos soldaditos de juguete, cada uno de los cuales porta una bandera mexicana. La tercera foto que evoca el marco infantil se encuentra en la segunda página de la lectura. Está colocada al centro y es una toma de plano general donde aparecen muñecos que, si tomamos como referencia los árboles del setting, parecería que son de tamaño humano. Apenas se logra distinguir que la muñeca más prominente de esta imagen porta un vestido típico del Estado de Veracruz y lleva en la mano la bandera de México, símbolo que por su tamaño y colorido capta la atención del observador. La fotografía que se encuentra a la izquierda de esta evoca el marco de la ESCUELA y perfila las ceremonias patrióticas. Tomada desde un plano general, presenta un setting escolar donde se reconoce la escolta de niños que lleva la bandera durante la ceremonia que se hace en honor a esta en las escuelas primarias. En la última fotografía aparece únicamente la bandera de México ondeante en contrapicado, con lo cual esta adquiere poder sobre el observador y comunica grandeza, ya que la mirada del lector tiene que dirigirse hacia lo alto, lo ideal.

Como se puede observar, en estos libros el submodelo de los símbolos nacionales perteneciente al modelo de MÉXICo vuelve a tomar fuerza. Aunque cuando 
se habla del país (24 oc.) nunca se utiliza la palabra patria, como en los libros de los sesenta, en estos manuales los símbolos nacionales ocurren más frecuentemente (26 oc.) que en sus predecesores, los libros de los setenta (11 oc.). Es decir, con la reiteración de estos símbolos (bandera, escudo, himno) y las fotografías de niños rindiéndoles homenaje (3 oc.) se le da al modelo de México un tinte más patriótico que los libros anteriores.

Por último, este modelo también comprende sitios concretos de la República mexicana. En los manuales se mencionan 10 lugares: "Ayer domingo fuimos al pueblo de Xochimilco” (MLP II, p. 474); para practicar la lectura de consonantes: "Hortensia vive en Huasca. Su papá es Hipólito Hernández. Su familia vive en el estado de Hidalgo desde hace tiempo" (MLP II, p. 356); y para hablar de los medios de transporte: “¿Cómo podemos ir a otros lugares de México? Cuautla, Cuernavaca, Yautepec” (MLP II, p. 370).

Así, de la construcción del modelo México derivan los siguientes ideologemas:

- "México contiene una gran variedad y riquezas naturales, climáticas y geográficas”.

- "México es el lugar donde nacimos y habitamos los mexicanos".

- "La bandera es México".

- “Sentimos cariño por el país y por lo tanto por la bandera también”.

- "Respetamos a la bandera y nos sentimos orgullosos de ella, por eso le hacemos ceremonias”.

\subsubsection{El modelo de la HISTORIA NACIONAL}

También en esta generación, el modelo de la HISTORIA NACIONAL se presenta al final de los manuales y, por lo tanto, también al final del ciclo escolar cuando los niños ya han adquirido más madurez. En contraste con las antiguas generaciones, en esta se hace más hincapié en la idea de que México tiene un pasado, pero sobre todo un presente que se proyectará hacia un futuro. En estos libros el modelo de HISTORIA NACIONAL está conformado por cuatro instanciaciones: la historia prehispánica (15 oc.), la prehistoria (4 oc.), los personajes históricos (18 oc.) y el presente de México (4 oc.).

Las primeras dos instanciaciones pertenecen al marco del PASADO DE MÉXICO y son nuevamente incluidas después de haber desaparecido de los libros de los setenta. En efecto, en dicha generación solo se hace alusión al pasado prehispánico mediante imágenes, pero no se dan explicaciones históricas y la prehistoria no es nombrada en absoluto. En la primera generación, en cambio, aparecen ambos submodelos en el libro de trabajo. En la tercera generación, la prehistoria y la historia prehispánica son incluidas en la unidad 8, módulo 4 "México y 
su pasado" (MLP II, p. 429). El título explícitamente abre el marco del PASADO que ha sido desarrollado durante toda la unidad 8 (MLP II, pp. 393-440). El título "México y su pasado" conceptualiza al país de manera prosopopéyica, es decir, como a una persona que tiene un pasado. Este concepto resulta menos abstracto y más fácil de entender para el escolar, ya que a lo largo de la unidad se hace referencia al pasado del niño y de su familia. La prominente imagen utilizada para introducir este módulo corresponde a una escultura perteneciente a alguna cultura prehispánica, con lo cual se fija dicho marco -el MUNDO PREHISPÁNICOdentro del modelo del PASADO DE MÉXICO (Fig. 26).

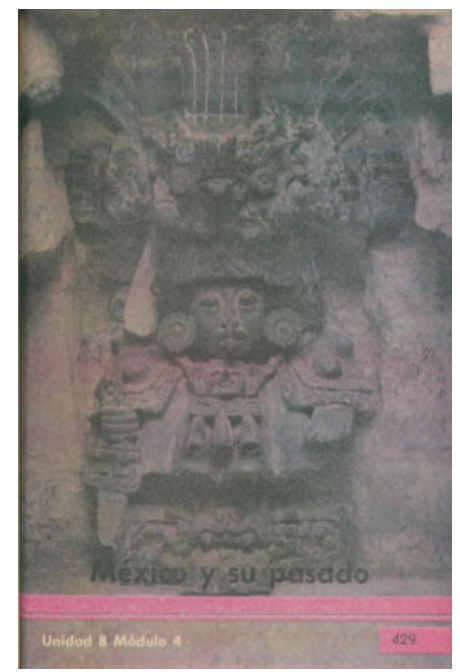

Fig. 26: Modelo de la HISTORIA: el pasado prehispánico (MLP II, p. 429).

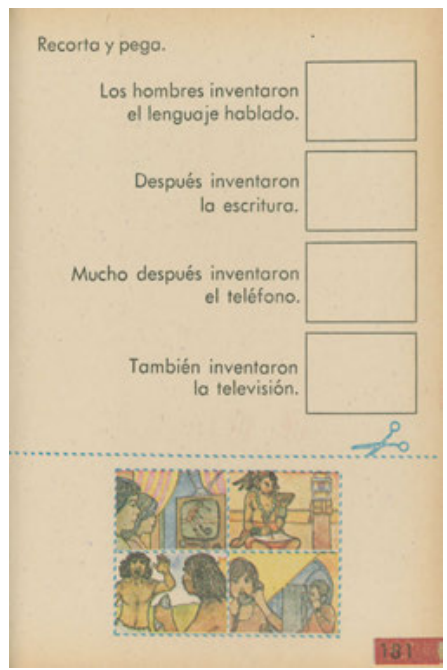

Fig. 27: El pasado prehispánico y una de sus instanciaciones: la cultura maya (LR II, p. 181).

Los ejemplos de estas representaciones los hemos referido anteriormente cuando ilustramos que el indígena es relegado al pasado, al folklor y es colocado dentro el marco del MUSEO (Fig. 21). Asimismo, pero con mucha más prominencia, son incluidos en este marco las esculturas que indexan el mundo prehispánico. También ya hemos hablado de la representación de la ciudad azteca que es conceptualizada con magnificencia como algo nuestro, "Nuestra capital ha cambiado" (MLP II, p. 437), pero que ha desaparecido a causa los españoles (Fig. 22). Este mismo texto abre los marcos de BELLEZA y MAJESTUOSIDAD: "Los aztecas fundaron México-Tenochtitlan en un lago. La ciudad era muy hermosa. Tenía palacios, templos y muchos canales” (MLP II, p. 437). Pero, ade- 
más, hace que se conceptualice al pueblo azteca como ingenioso o increíble, por haber fundado una ciudad sobre un lago.

Un miembro periférico de la categoría de culturas prehispánicas que aparece en estos libros es la maya ( 2 oc.). Esta cultura es relacionada con el marco de la LENGUA y, a diferencia de la azteca, es conceptualizada como lejana del centro deíctico pero viva: "Algunos hablan otras lenguas también muy bonitas como el maya” (MLP II, p. 389). Esta cultura es relacionada también con el marco de la escritura en el libro recortable (LR II, p. 181) (Fig. 27), donde se debe elegir el dibujo de un hombre maya escribiendo y pegarlo junto a la oración "Después inventaron la escritura". Aunque los mayas solo son una elaboración metonímica del sujeto de todas las oraciones los hombres, la oración que les corresponde los relaciona directamente con la invención de la escritura, por lo que esta cultura se conceptualiza como muy importante.

La PREHISTORIA es mencionada muy brevemente en el módulo "México y su pasado".

En estas páginas se confirma la relación entre museo y pasado: "El otro día la maestra nos llevó a un museo. Allí vimos que antes, hace muchísimos años, ya había hombres en México” (MLP II, p. 435) (Fig. 28). Esta lectura abre también el marco del MIEDO cuando el narrador habla de los grandes animales que estos hombres enfrentaron. Las imágenes de maquetas de hombres cazando un mamut y un búfalo y la activación del marco del MIEDo hacen que indirectamente se atribuya a estos hombres, categorizados como mexicanos, un carácter valiente y fuerte.

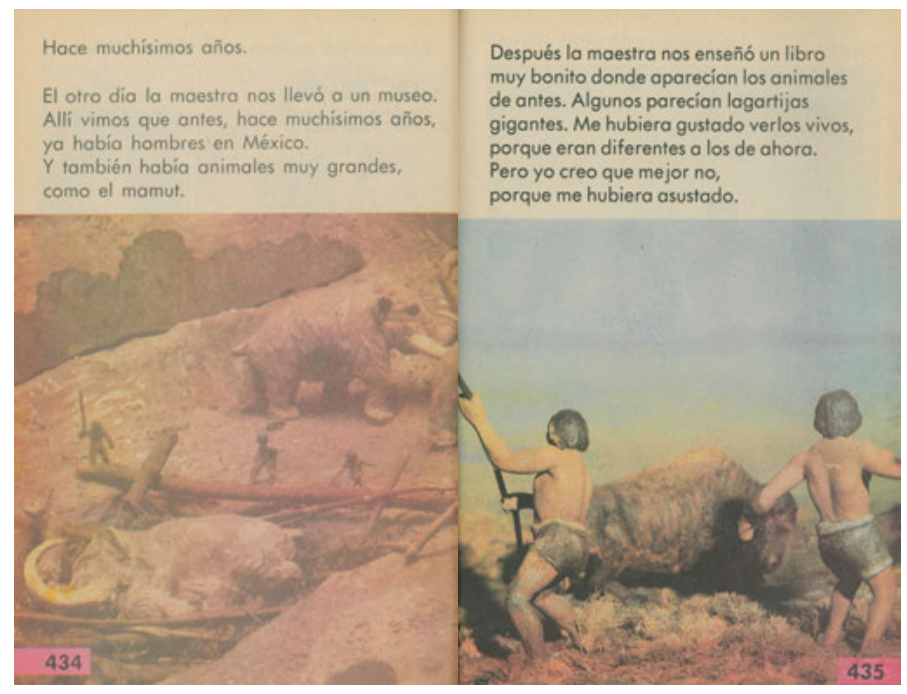

Fig. 28: Modelo de la HISTORIA NACIONAL: la prehistoria (MLP II, pp. 434-435). 
Otra de las elaboraciones de la HISTORIA NACIONAL es la de los personajes históricos. Los manuales de la tercera generación omiten los textos referentes a Benito Juárez y a Francisco I. Madero de los libros precedentes, pero mantienen intactas las lecturas sobre Miguel Hidalgo y Netzahualcóyotl. De esta manera, permanecen las ideas del pueblo como promotor del cambio social, la gran emoción que provoca la celebración de la Independencia y Netzahualcóyotl como culto y bondadoso representante de la cultura azteca. En ambos casos, sin embargo, las imágenes que las ilustran son completamente diferentes a las que aparecen en los libros anteriores. En el caso de la lectura dedicada a Miguel Hidalgo se utilizan tres imágenes en lugar de dos: una foto del Zócalo de la Ciudad de México donde se ve como fondo el Palacio Nacional, mientras que, encuadrada en primer plano, aparece la bandera mexicana. Por su tamaño y colorido, este símbolo tiene la mayor saliencia dentro de la imagen (Fig. 29).

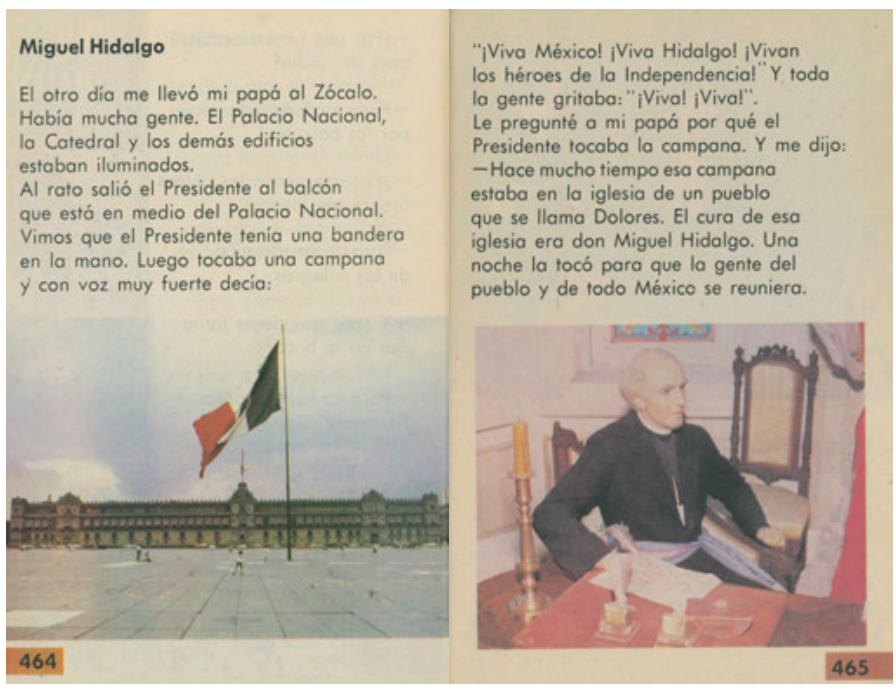

Fig. 29: Modelo de la HISTORIA NACIONAL: personajes históricos (MLP II, pp. 464-465).

La segunda imagen de la lectura es una foto de una figura de cera que representa a Hidalgo. El personaje se encuentra sentado, escribiendo, y es posicionado de manera oblicua, por lo que no establece ningún contacto con el observador. La tercera imagen (Fig. 30) le quita fuerza a la idea que transmite el texto debajo de esta. Esto es, aun cuando la gente es la figura o trajector e Hidalgo el fondo o landmark, la representación visual hace que se focalice el personaje de Hidalgo y los caudillos representados por muñecos, los cuales fueron colocados casi de frente y muestran la mayor parte de su rostro. El realismo que comunica la foto- 
grafía se atenúa, sin embargo, mediante el uso de muñecos que tratan de representar a los personajes.

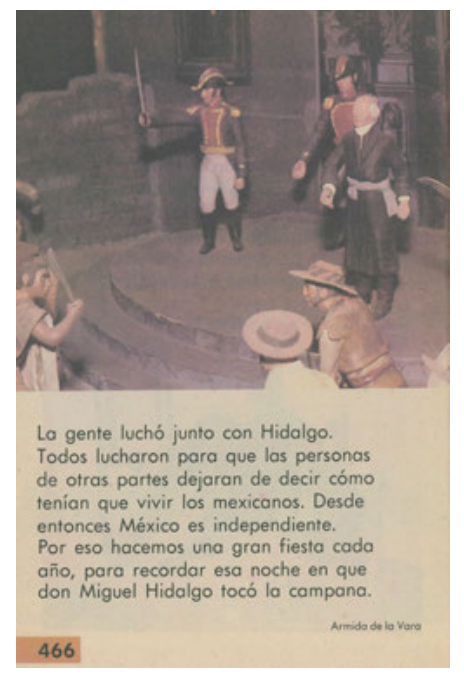

Fig. 30: Atenuación de la conceptualización del pueblo como promotor del cambio (MLP II, p. 466).

Netzahualcóyotl es otro de los personajes históricos que persistió en esta generación. Como habíamos mencionado, el personaje remite directamente al mundo prehispánico. Las propiedades de majestuosidad, cultura y bondad que le atribuye la lectura son evidenciadas a través de la nueva imagen seleccionada para acompañar el texto. A diferencia de la imagen del libro de los setenta, que representaba al personaje a través de pictogramas evocando con esto lo extraño y lejano (Fig. 22, cap. 5), esta vez se optó por una figura humana, en color, de tipo demanda, en plano americano (cowboy shot) y encuadrada en primer plano (Fig. 31). La posición frontal, la mirada y la sonrisa hacen que este personaje entre en contacto imaginario con el observador. Además, las flores que tiene en la mano lo ponen en relación con la parte verbal que abre el marco de la AMISTAD. Todo lo anterior hace que se genere una sensación de simpatía hacia el personaje. El penacho que porta en la cabeza a modo de corona y los brazaletes de oro refirman el marco de la realeza evocado por el seudónimo "el rey poeta". El setting que aparece de fondo comprende elementos asociados con la poesía: una noche estrellada con nubes, la luna, un prado verde y cactáceas propias de México con las cuales se ha iden- 
tificado al país (el nopal - opuntia ficus indica-, que también se encuentra en el escudo nacional, y los magueyes, asociados al agave tequilero). La luna, que se encuentra en un segundo plano, contiene la representación de un conejo. Esta evoca la leyenda azteca de "El conejo en la luna”, la cual cuenta que un conejo ofreció su vida al dios Quetzalcóatl para salvarlo de la inanición y este lo premió plasmando su figura en el astro para que fuera recordado por siempre. La leyenda no aparece explícitamente en los manuales de primero sino en Mi libro de segundo. Lecturas (1981, pp. 98-100) de esa misma generación. Aun así, se presta para que se hable de la leyenda durante la lección. La elección de la imagen, pues, corresponde con los marcos de AMISTAD y BONDAD que implica la poesía de Netzahualcóyotl y que se pondrán en relación con el marco del MUNDO PREHISPÁNICO, reafirmándose como parte de él.

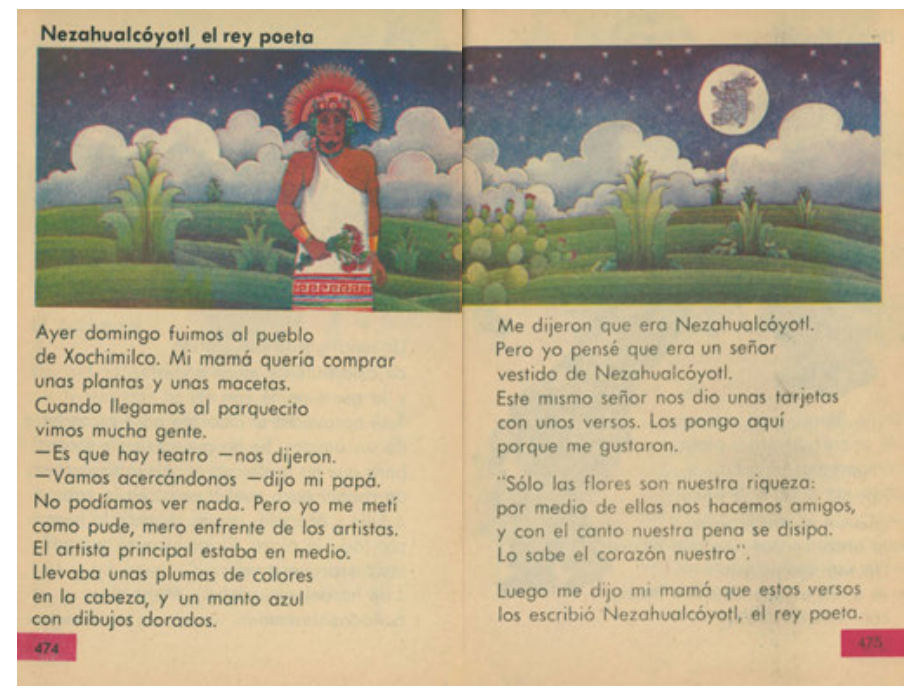

Fig. 31: Modelo de la HISTORIA: personajes históricos del mundo prehispánico (MLP II, pp. 474-475).

La última página donde aparecen personajes históricos es la imagen que abre el módulo 4 "Somos mexicanos" de la unidad 7. En la fotografía (Fig. 32) se observan dos niños cuyo fenotipo corresponde al del mexicano prototípico que se disponen a poner el disco del himno nacional.

El setting es escolar; se reconoce que es la oficina del director, porque sobre el escritorio se puede ver parte del letrero de presentación que lleva inscrito su nombre y su posición ("ING. ANTONIO R . . . DIREC . . . ”). En la parte superior, 


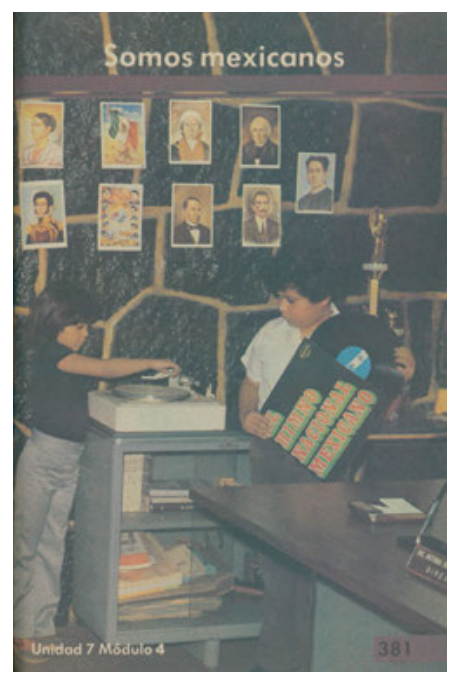

Fig. 32: Modelo de la HISTORIA: los personajes históricos (MLP II, p. 381).

pegadas a la pared se observan ocho litografías de personajes históricos (Josefa Ortiz de Domínguez, José María Morelos, Miguel Hidalgo, Los Niños Héroes, José María Pino Suárez, Leona Vicario, Vicente Guerrero y Benito Juárez), además de otra donde se plasma la bandera de México. Tales imágenes captan la atención gracias a su mayor iluminación y a la posición superior que evoca la metáfora LO BUENO/DESEABLE/IDEAL ES ARRIBA. La disposición elevada brinda a los personajes un halo de divinidad. La imagen de tipo transaccional indica, mediante el vector formado por el brazo del niño de la izquierda, el tocadiscos y su intención que parece requerir un esfuerzo, ya que la figura infantil está parada sobre las puntas de los pies. Esta acción hace que se dirija la mirada hacia el fondo o landmark, es decir, hacia el disco que el otro niño está sacando de la cubierta y que en letras mayúsculas deja claro el título. Ninguna de las dos figuras establece una relación con el observador, sin embargo, lo que comunican es su deseo, a pesar del esfuerzo que implica, de escuchar el Himno.

La última instanciación del modelo de la HISTORIA NACIONAL es el del presente ( 4 oc). Esta elaboración se enfatiza más en esta generación que en las precedentes. Habíamos ya citado dos de los cuatro ejemplos al hablar del modelo de EL OTRO (Figs. 23 y 24). Como ocurre en la generación de los setenta, la imagen que se quiere dar del México actual es de modernidad. Esto se representa mediante la arquitectura y los medios de transporte (Fig. 33). 


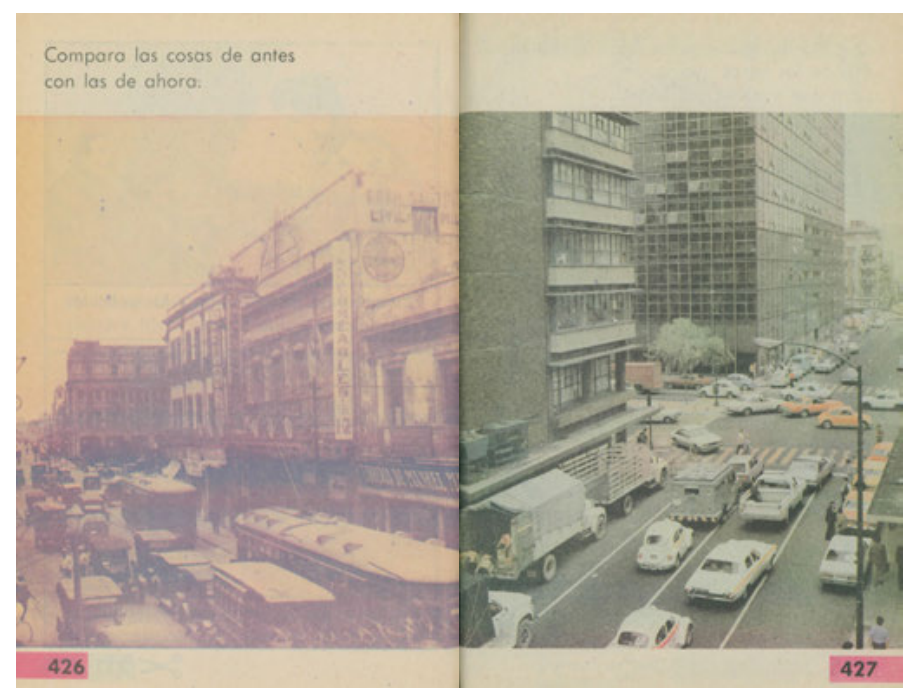

Fig. 33: El presente de México, instanciación del modelo de la HISTORIA (MLP II, pp. 426-427).

En todas las imágenes que acompañan la idea de México moderno aparecen edificios altos y las tomas son aéreas en picado, lo cual hace que los coches se vean muy pequeños. En la Fig. 33, por ejemplo, la foto que representa el pasado es poco nítida y, aunque también está tomada desde lo alto, no alcanza la altitud de la foto que representa la modernidad. Además, el hecho de que en la segunda foto no aparezcan los techos de los edificios, refuerza la sensación de altura. Otro ejemplo lo encontramos en el mismo módulo. En estas páginas también se hace un contraste entre el pasado y lo que se quiere dar a entender como presente (Fig. 34). En este caso, mientras que la imagen de la época colonial crea la sensación de algo lejano y ajeno a la realidad del lector, la altura desde la que está tomada la segunda foto (aún mayor que la de la Fig. 33) le otorga al observador poder sobre la imagen y le reafirma la idea de que mientras más altas son las construcciones, mayor es la modernidad.

Así, los ideologemas que promueven los libros con respecto al modelo de la HISTORIA NACIONAL SOn:

- “Nuestro pasado prehispánico era majestuoso".

- "Los aztecas eran asombrosos, ingeniosos y cultos”.

- "Los personajes históricos son dignos de reconocimiento".

- "El pasado de México es importante por lo que merece estar en museos”. 


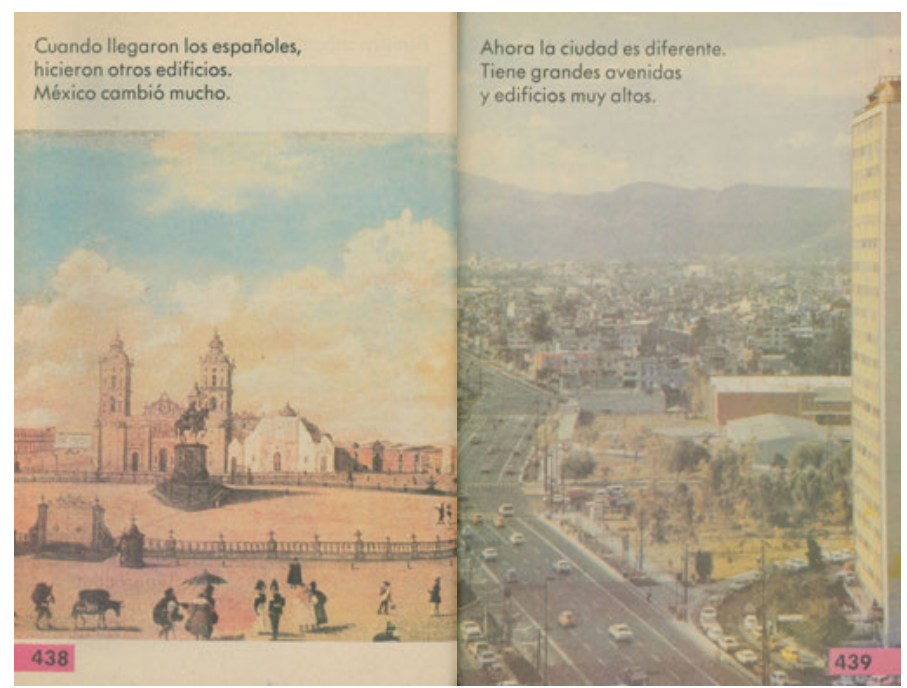

Fig. 34: La arquitectura, símbolo de modernidad (MLP II, 438-439).

- “Actualmente México es un país moderno”.

Como en las dos generaciones anteriores, incluimos a continuación el esquema radial (Gráfico 3) donde se puede observar el peso que los productores textuales le dieron a los modelos cognitivos y las relaciones que entre ellos se establecen. 


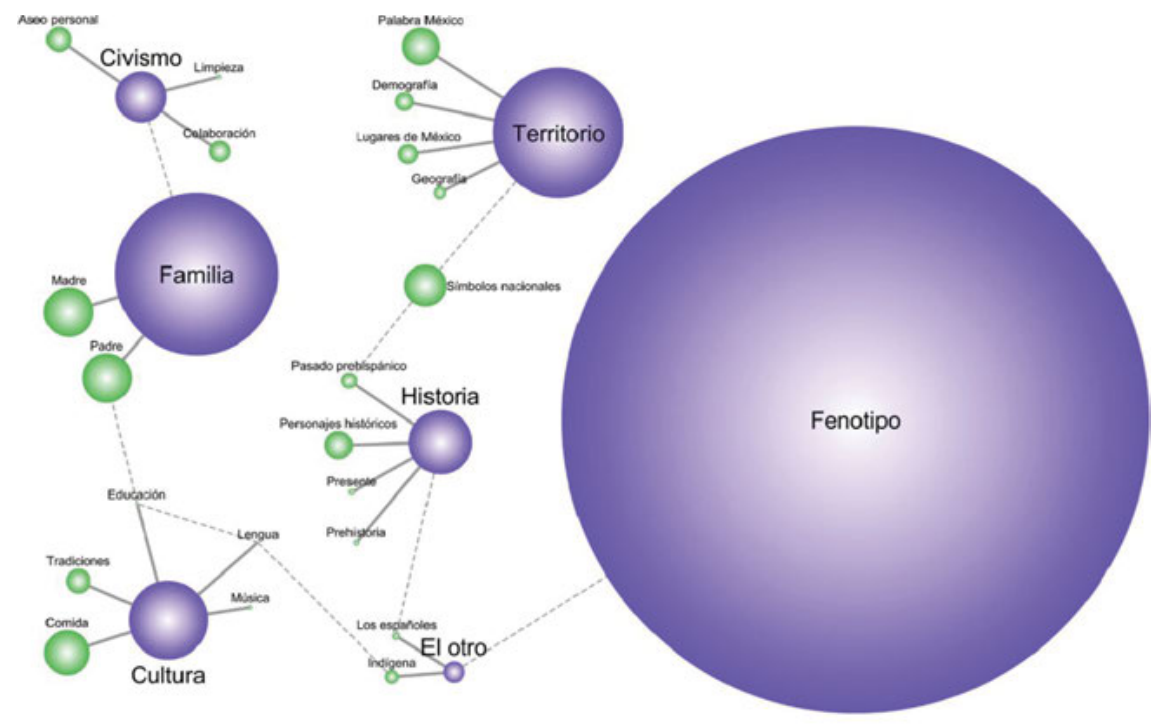

\footnotetext{
Modelos cognitivos

Instanciaciones

_ Pertenencia directa a los modelos cognitivos

- -- Relaciones entre modelos e instanciaciones
}

Gráfico 3: Modelos cognitivos y sus instanciaciones en la tercera generación de LTG. 
